ISSN 1996-1073

www.mdpi.com/journal/energies

Article

\title{
How Will Hydroelectric Power Generation Develop under Climate Change Scenarios? A Case Study in the Upper Danube Basin
}

\author{
Franziska Koch ${ }^{1, *}$, Monika Prasch ${ }^{1}$, Heike Bach ${ }^{2}$, Wolfram Mauser ${ }^{1}$, Florian Appel ${ }^{2}$ and \\ Markus Weber ${ }^{3}$
}

1 Department of Geography, Ludwig-Maximilians-Universität München, Luisenstr. 37, Munich 80333, Germany; E-Mails: m.prasch@1mu.de (M.P.); w.mauser@1mu.de (W.M.)

2 VISTA GmbH, Remote Sensing in Geosciences, Gabelsbergerstrasse 51, Munich 80333, Germany; E-Mails: bach@vista-geo.de (H.B.); appel@vista-geo.de (F.A.)

3 Commission for Geodesy and Glaciology, Bavarian Academy of Sciences and Humanities, Alfons-Goppel-Str. 11, Munich 80539, Germany; E-Mail: wasti.weber@kfg.badw.de

* Author to whom correspondence should be addressed; E-Mail: f.koch@iggf.geo.uni-muenchen.de, Tel.: +49-89-2180-6687; Fax: +49-89-2180-6675.

Received: 30 June 2011; in revised form: 6 September 2011 / Accepted: 22 September 2011 / Published: 30 September 2011

\begin{abstract}
Climate change has a large impact on water resources and thus on hydropower. Hydroelectric power generation is closely linked to the regional hydrological situation of a watershed and reacts sensitively to changes in water quantity and seasonality. The development of hydroelectric power generation in the Upper Danube basin was modelled for two future decades, namely 2021-2030 and 2051-2060, using a special hydropower module coupled with the physically-based hydrological model PROMET. To cover a possible range of uncertainties, 16 climate scenarios were taken as meteorological drivers which were defined from different ensemble outputs of a stochastic climate generator, based on the IPCC-SRES-A1B emission scenario and four regional climate trends. Depending on the trends, the results show a slight to severe decline in hydroelectric power generation. Whilst the mean summer values indicate a decrease, the mean winter values display an increase. To show past and future regional differences within the Upper Danube basin, three hydropower plants at individual locations were selected. Inter-annual differences originate predominately from unequal contributions of the runoff compartments rain, snow- and ice-melt.
\end{abstract}


Keywords: climate change; PROMET; hydroelectric power generation; runoff components; GLOWA-Danube; Upper Danube basin

\section{Introduction}

Since climate change will certainly increase global air temperature, considerable regional impacts on the availability of water resources will occur concerning quantity and seasonality [1]. This will affect all kinds of water users, water suppliers and water management structures. Hydropower has in total a large proportion of the world's energy production, which comprised $15 \%$ of the world's total electric energy generation in 2008 [2] following the fossil energy resources carbon, mineral oil and natural gas. In regions with high precipitation rates and steep elevation gradients, like the European Alps, hydropower represents the main electric energy supply. Alpine countries such as Austria and Switzerland supply over the half of their electric energy mix with hydropower. In Austria, $62 \%$ of the internal gross electricity supply was produced by hydropower for the year 2009 [3] and in Switzerland $56.5 \%$ for the year 2011 [4]. Moreover, recent significant worldwide increases in hydropower capacity are projected, whereby, the capacity growth in 2008 was second only to wind power [2]. The future development of hydroelectric power generation and its sensitivity to climate change is a relevant and prevailing issue but is not yet well discussed albeit its importance [5]. Hydropower will be impacted by climate change in a varying degree depending on the region and hydropower type; thereby runoff-river power plants as well as reservoir hydropower plants will be affected. Whereas accumulation hydropower production is rather robust to climate variability due to the possibility of adaptation in storage management strategy, runoff-river power plants are directly affected by climate change impacts on runoff in its quantity and seasonality. Regarding reservoir power plants, production strategies can be modified by taking the advantage of the reservoir storage volume and adapting them to climate change effects and possible future changes in electricity demand. However, adaptation is only possible to a certain degree, because they will also be affected by changes in the mean annual runoff and only have limited elasticity in their management plans due to a seasonal runoff shift.

Hydropower as a renewable and sustainable electric energy provider is closely linked to the hydrological situation of a certain region. Hydroelectric power generation depends largely on the regional catchment-based water balance and reacts sensitively to changes of the hydrological cycle in respect to water quantity and seasonality. Seasonal and quantitative changes in precipitation and evapotranspiration lead to inter-annual changes in runoff and hydrological storage, e.g., soil water content, snow cover and glaciers as well as their mean annual amount. Moreover, hydrological periodicities of low-flows and floods as well as the snow and ice storage, especially in mountainous areas, play an important role for runoff generation. Under climate change conditions diverse changes of the mentioned water balance components are expected for the European Alps in the next decades, which are considered by several recent studies [6-18]. The hydrological changes can be expected to consist of are considerable changes in seasonal precipitation patterns indicating an increase in winter and a decrease in summer precipitation, a general increase of mean annual evapotranspiration, a decrease in mean annual runoff and seasonal changes of runoff regimes as well as a decrease of the 
snow and ice storage. Regarding runoff regimes, a future decrease in snow storage and therefore also in snow-melt leads to an increasing pluvial character until 2060 for the whole Upper Danube basin [11]. The future start of the snowmelt period will be earlier in the year leading to a shift of the hydrological regime and of the seasonal runoff peak. Only in the glaciated alpine head-watersheds, changes of the ice storage play a considerable role [10]. As analyzed in various mountainous catchments, the latter undergo a transition from an ice-melt dominated runoff regime in the past to a more snow-melt dominated regime in the future with a significant shift of the runoff peak from summer to spring $[10,11,13,19,20]$.

Regarding research on future impacts on hydropower, most existing studies analyse the future development of the water cycle in terms of runoff and project changes to the future hydroelectric power generation. Various studies show a mean annual decline of runoff as well as seasonal runoff changes for different regions of the European Alps thus forecasting a future reduction of the mean annual hydroelectric power generation [5,7,21-24]. Besides for the European Alps, studies on climate change impacts on hydropower were carried out also for other regions of the world. For example, regarding the western U.S., several studies [25-28] came to similar findings in their respective region, showing a future decline in mean annual hydroelectric power generation and a seasonal shift due to changes of the hydrological regime. Regarding the European Alps, Schaefli et al. [5] showed a decline in runoff and subsequent hydroelectric power generation for the time period 2070-2099 in a single highly glaciated catchment of a reservoir power plant in Switzerland which was mainly triggered by a decrease in precipitation, glacier retreat and an increase in evapotranspiration. Further, Stanzel and Nachtnebel [21] estimated the changes of the water balance and attributed hydroelectric power generation for the entire Austrian territory using hydrological model outputs resulting in a decrease of 6 to $15 \%$ depending on the climate scenario for the time period 2025 to 2075 . Due to climate change impacts on seasonal water availability and runoff regimes, an increase in hydroelectric power generation was observed in the winter, whereas a decrease could be found in the summer. Another recently published Austrian study [7] confirms the shift from summer to winter production, but shows only small mean annual changes until 2050. Nonetheless, most of the studies do not directly model the changes of hydropower under altered climate conditions but rather try to assign it to altered runoff conditions.

In this study, the hydroelectric power generation is calculated directly as model output on a high temporal resolution of one hour for single hydropower plants within a large scale catchment. This means that all hydropower plants of the watershed can be considered in a parallel way with their individual parameterisations and the runoff situation for each model time step. The future development of hydroelectric power generation was analysed in detail for the mountainous Upper Danube basin in Central Europe. The study was carried out within the frame of the interdisciplinary research project GLOWA-Danube [29-31], which explored various physical and social impacts of Global Change on water resources of the Upper Danube basin in a regional focus for the next 50 years. To consider all important hydrological components, which have an impact on the hydroelectric power generation and their development due to climate change, the physically-based and fully spatially distributed model Processes of RadiatiOn, Mass and Energy Transfer (PROMET) [32] was used. It strictly conserves mass and energy and is not calibrated against measured discharge at gauges. PROMET is coupled with a specially developed hydropower module, which calculates the hydroelectric power generation for 
each hydropower plant above $5 \mathrm{MW}$ bottleneck capacity on an hourly resolution. To cover a possible range of future uncertainties, 16 climate scenarios of four underlying regional climate trends were taken as meteorological drivers for PROMET, which were defined from different ensemble outputs of a stochastic climate generator based on the IPCC-SRES-A1B scenario. The analysis thereafter shows a range of possible future developments of hydroelectric power generation for the entire investigation area and three hydrologically different locations, which diverge in their degree of alpine character.

\section{Hydropower in the Upper Danube Basin}

The study area, covering parts of Germany and Austria and small parts of Switzerland, Italy and the Czech Republic, is defined by the Achleiten outlet gauge near Passau after the confluence of the rivers Inn and Danube (Figure 1). The Upper Danube is one of Europe's most important catchments and is a main water source for the downstream Danube region until its discharge into the Black Sea.

Figure 1. Upper Danube basin in Central Europe.

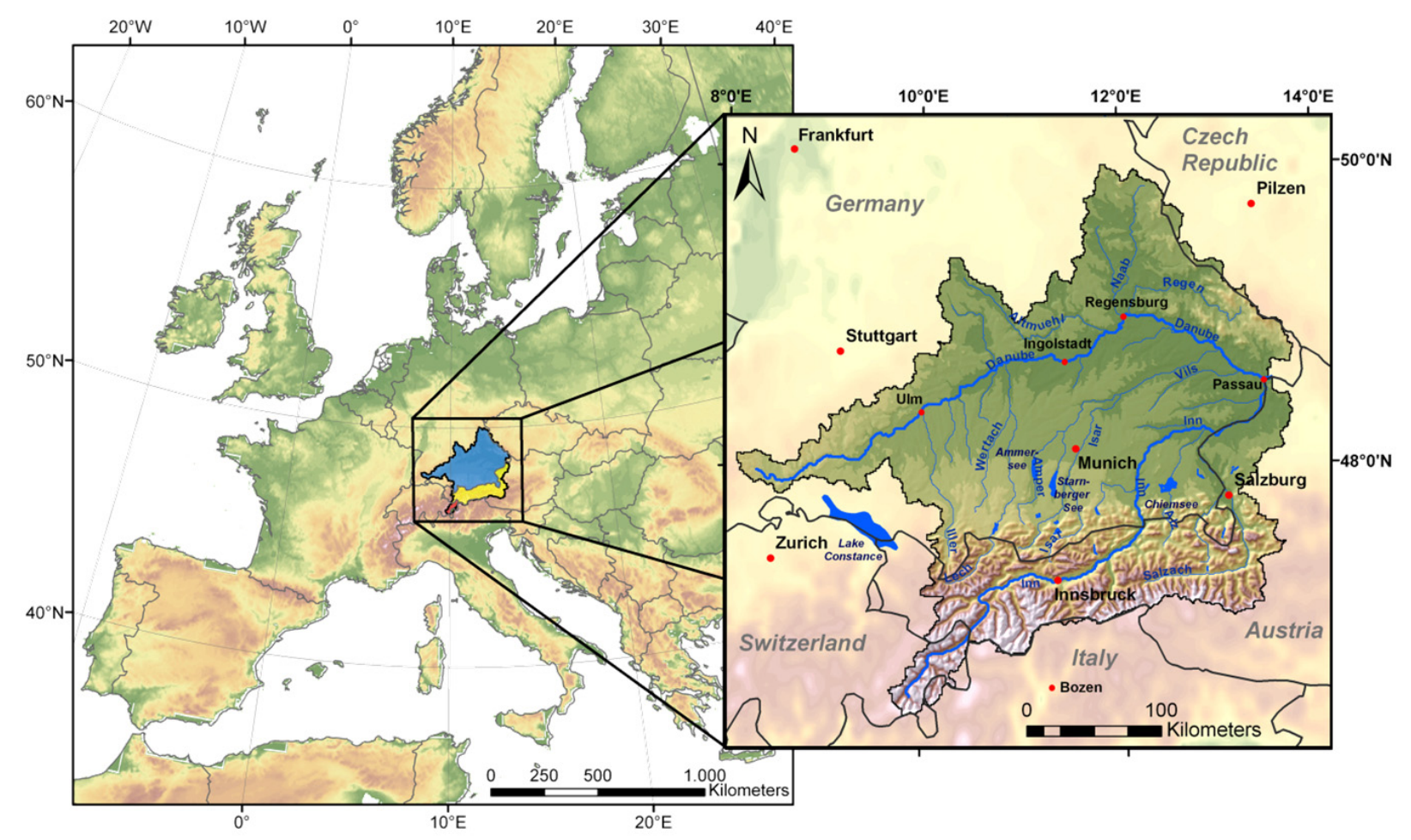

The catchment is structured by the Alps and the alpine valleys in the southern part, the alpine forelands and the tertiary hills in the middle part, and the Danube lowlands and the mid-altitude mountains of the Bavarian Forest and the Swabian Alb in the northern part. The river Danube is characterized on the one hand by the northern tributaries of the mid-altitude mountains and on the other hand by the southern tributaries originating in the Alps. It is fed to a high portion by the river Inn and its alpine headwaters, which are strongly influenced by snow storage [11,33] and are further characterized by approx. 550 glaciers with an area of $358 \mathrm{~km}^{2}$ in the year 2000, predominantly situated in the Central Alps [11]. The lowlands of the tributaries Inn, Iller, Lech, Isar and Salzach as well as the downstream Danube heavily depend on significant amounts of water from the alpine head-watersheds 
and are influenced also by their seasonality. Especially in summer, the Alps play an important role to the lower catchments in runoff delivery $[11,12]$.

Figure 2. The Upper Danube basin with its main rivers, ice storage, hydropower plants and reservoirs. The locations of the hydropower plants Donauwoerth, Wasserburg and Kaunertal, analyzed in Section 4.3, are marked with a pink circle.

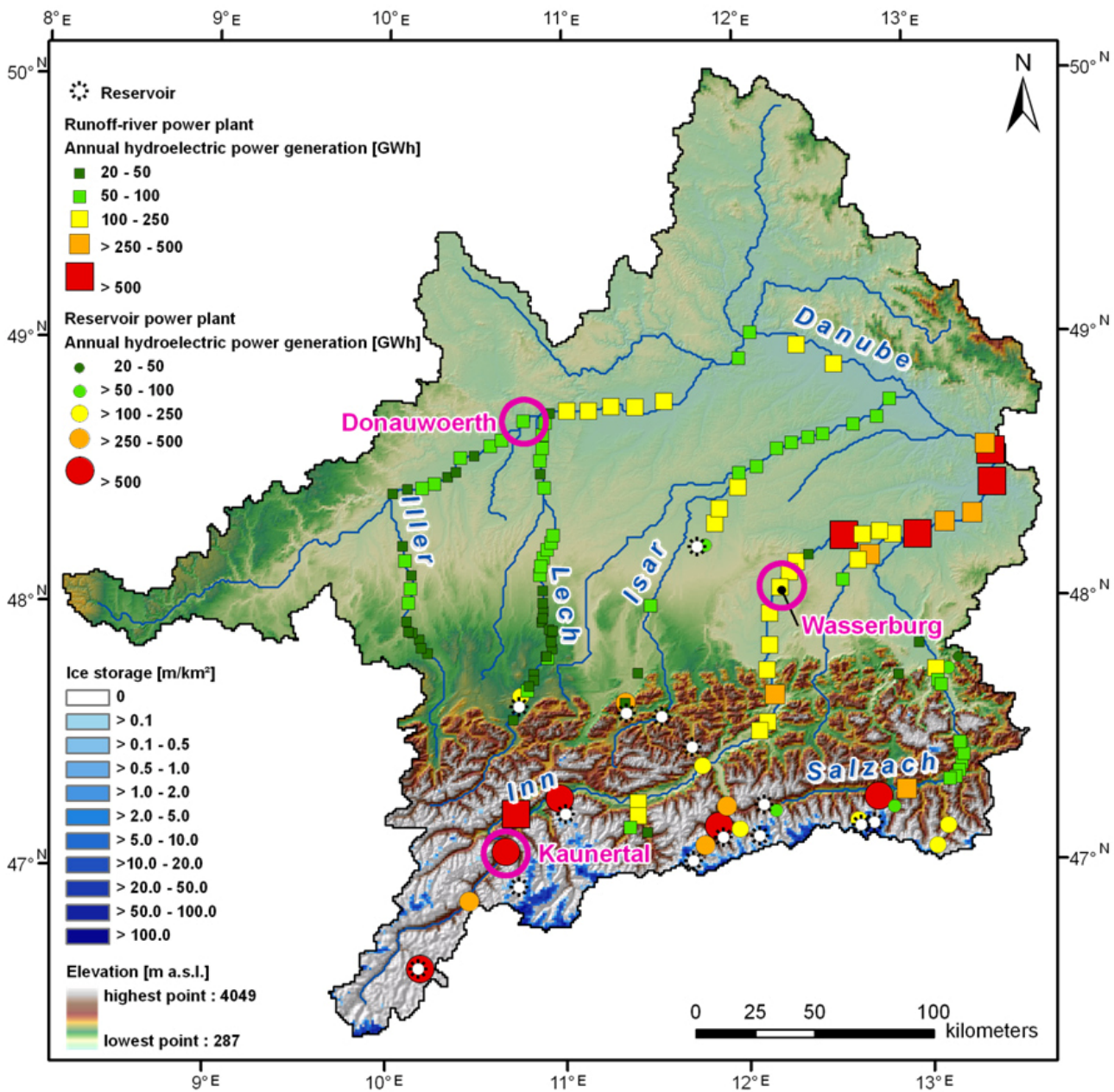

The Upper Danube basin covers an area of $76,660 \mathrm{~km}^{2}$ and is characterized by its mountainous topography with steep elevation gradients. The altitudes range from $4049 \mathrm{~m}$ a.s.l at Piz Bernina in the Central Alps to $287 \mathrm{~m}$ a.s.l at the Achleiten outlet gauge. Depending on altitude and region, the mean annual temperature varies from -4.7 to $+9.0^{\circ} \mathrm{C}$ and the mean annual precipitation in the range of $650 \mathrm{~mm}$ in the northern part to more than $2000 \mathrm{~mm}$ in the Alps. The mean annual evapotranspiration ranges from 100 to $700 \mathrm{~mm}$ per year; the mean annual runoff from 150 to $1750 \mathrm{~mm}$ per year. Besides these physical gradients, the heterogeneous research area shows strong gradients in social factors and processes. Water resources are intensively and differently used by agriculture, tourism, industry and energy providers [29]. Because of high precipitation and runoff rates as well as steep elevation gradients in the Alps, the Upper Danube basin is ideally suited for hydroelectric power generation. In the Austrian province of Tyrol, hydropower supplies most of the inland electricity demand [34]. In the German Free State of Bavaria which covers more than half of the study area, hydroelectric power generation amounts to about $18 \%$ [35]. For this study all hydropower plants in the Upper Danube basin 
covering a bottleneck capacity of more than $5 \mathrm{MW}$ are considered. This amounts to 140 large power plants, comprising 118 runoff-river power plants and 22 reservoir power plants (Figure 2).

About $70 \%$ of the total hydroelectric power generation in the Upper Danube watershed is produced by runoff-river power plants providing base-load energy, whereas about $30 \%$ is produced by reservoir power plants presently covering both, mid-load and peak-demand energy, with an elevated electricity demand in winter. In winter the discharge of the river Inn as main Alpine tributary therefore shows a characteristic daily oscillation during working days. The runoff-river power plants are mainly situated at the river Danube and its larger tributaries Iller, Lech, Isar, Inn and Salzach with a range of annual hydroelectric power generation of 20 to more than $500 \mathrm{GWh}$. Most of the runoff-river power plants generate 50 to $250 \mathrm{GWh}$. Because of high mean annual runoff, the biggest runoff-river power plants are installed at the river Inn. Nearly all of the reservoir power plants with a range of 50 to $1000 \mathrm{GWh}$ are situated in the southern part in the Central Alps.

\section{Methods}

To determine the hydroelectric power generation of each hydropower plant, a specific hydropower module was developed. The module is coupled with the hydrological model PROMET [32]. After describing PROMET and the components considering snow- and ice-melt, channel flow and man-made hydraulic structures (Section 3.1), the coupled hydropower module (Section 3.2) is explained in detail and its validation (Section 3.3) is shown. The required meteorological input data for PROMET are explained in Section 3.4.

\subsection{The Hydrological Model PROMET and Its Components Considering Snow- and Ice-Melt, Channel} Flow and Man-Made Hydraulic Structures

The hydrological model PROMET is fully spatially distributed, raster-based with a spatial resolution of $1 \mathrm{~km}^{2}$ and a temporal resolution of one hour in the selected case study. It covers the following components: land surface energy and mass balance, vegetation, snow- and ice-melt, soil hydraulic and temperature, groundwater, channel flow and man-made hydraulic structures. The model is driven by meteorological input data (see Section 3.4). All meteorological, hydrological and land surface components, including land-atmosphere energy and mass exchange, snow and ice accumulation and ablation, flows in the saturated and unsaturated zones, channel flows, and flows through lakes and man-made structures are fully coupled. Thereby PROMET strictly follows the principle of conserving mass and energy fluxes. To simulate these processes, spatial input of topography, land use, glacier extent and ice thickness, soil texture and meteorology are necessary for each grid cell. Moreover, soil, vegetation and runoff parameters, as well as parameters and operation rules for man-made hydraulic structures are implemented in the model. The PROMET input data are described in detail in Mauser and Bach [32]. All model components were validated in detail and the model was and is applied in different watersheds [32,36-42]. PROMET is not calibrated using historical runoff measurements at gauges to preserve its predictive power. Calibration of physically-based hydrological models to historical streamflows generally leads to a good model performance as long as boundary conditions like climate, land use or hydraulic structures stay unchanged. It cannot be expected however that the model performance is equally good under changing future boundary conditions [32,43]. Besides its 
direct impact on hydrology, climate changes may also change the characteristics of a basin (e.g., through the removal of glaciers) in a way that calibration to past streamflow data, which included the influence of the glaciers, may force the model into inadequate simulations because it is calibrated to a different watershed. Past streamflow data also includes the influences of the existing man-made reservoirs or water transfers. Calibration therefore may become invalid in a strict sense as soon as new structures alter the hydrologic behavior of the watershed. Uncalibrated models offer the possibility to study the effect of adaptation strategies to climate change through, e.g., the installation of new storages or strategic changes in land use (irrigation, deforestation). Nevertheless, the complexity of non-calibrated models should not result in not understanding the underlying processes anymore $[39,44]$. However, all hydrological impact studies have to deal with uncertainty of, e.g., climate change, the impacts of economic change, population development and different management practices like changes in irrigation and water supply. They therefore rely on ensembles of climate change trajectories and scenarios for the additional future developments, which have to be documented thoroughly.

For this study the model components considering snow- and ice-melt, channel flow and man-made hydraulic structures are most important and will be described shortly in the following. The component considering snow- and ice-melt includes the SUbscale Regional Glacier Extension Simulator (SURGES) module [11,39], which calculates the energy and mass balance and accordingly water equivalent and melt rate of the snow and ice storage. The modelling of snow-melt takes the liquid water storage of a snow pack and rainfall on the surface of the snow cover into account. The module differentiates between solid or liquid state of precipitation using an empirically derived wet-bulb temperature threshold. Melting conditions are indicated by the surface energy balance $[33,40]$. The details of the glacier topography are parameterized by an area-elevation distribution related to frameworks grid. The three main processes are accumulation, ablation and ice flow. Because changes in the glacier geometry are considered, the module can be used for future long-term simulations [11].

Concerning the channel flow component, it is assumed that each grid cell is part of a channel network, whereby all grid cells are hydraulically connected through topography by using a digital elevation model. Each grid cell then transfers the channel flow to its hydraulic neighbour. Flow velocities and changes of water storage are considered by the Maskingum-Cunge method [45] modified by Todini [46]. The routing component also considers runoff retention in lakes [32].

The man-made hydraulic structures component represents the hydraulic behaviour of reservoirs, which can store channel flow and water transfers. The operation of water transfers as artificial hydraulic connections works with monthly-based operation plans. Its outflow is also operated using a monthly look-up table plan, which translates the storage volume into discharge. This monthly storage-discharge relation allows for a shift of the reservoir inflow and outflow during the course of the year with the main present purpose to store the annual snow- and ice-melt in summer and use it for low-flow augmentation in winter in alpine areas. Each reservoir operates individually by allowing flexible water management strategies, e.g., for hydroelectric power generation or flood protection. The management rules were implemented following the general operation rule suggestions presented by Ostrowski and Lohr [47], which consider normal reservoir operation as well as operation during high and low water availability, taking minimal and maximal discharge capacities, and storage volumes into account. When maximum storage volume is reached, the reservoir switches into a spillway discharge mode. 
Each reservoir is characterized by its individual storage volume, storage zoning and mean in- and outflow characteristics. Since detailed information on the actual operation of the reservoirs is not publicly available, all available information from literature, personal contacts and data on reservoir in- and outflows and lake levels was used to set up the individual monthly-based operation scenarios for all reservoirs. The scenarios assume that to use the reservoir storage efficiently, the reservoir mean annual outflow is oriented towards the mean annual inflow, whereby the reservoir filling can vary seasonally between 20 and $80 \%$. Because forecasting is not possible with this module, fillings over $80 \%$ are held free due to flood events. Below $20 \%$ the outflow is reduced to the set minimal outflow. The operation scenarios refer to present conditions. Throughout the following study of the impact of climate change on hydropower production these reservoir management scenarios were assumed unchanged for the future as a first order approach. A detailed analysis of the adaptation potential of changes in the operation scenarios is beyond the scope of this study. Figure 3 shows the operation scenario for the Gepatsch reservoir. It is the second-largest man-made reservoir in the watershed, located in a glaciated, highly alpine characterized head-watershed and contains a total volume of 139 million $\mathrm{m}^{3}$ of water. The operation scenario considers the runoff components snow- and ice-melt. This means that in times with high melting rates (May to October) more water will be stored by discharging less runoff at the same storage volume than in months with smaller or zero melting rates (November to April). From Figure 3 it becomes clear that, although principally possible in the module, the operation scenarios do not reproduce the actual operation of these reservoir power plants, which to a certain degree depend on the actual energy demand.

Figure 3. Monthly-based look-up table plan of the operation of the Gepatsch reservoir.

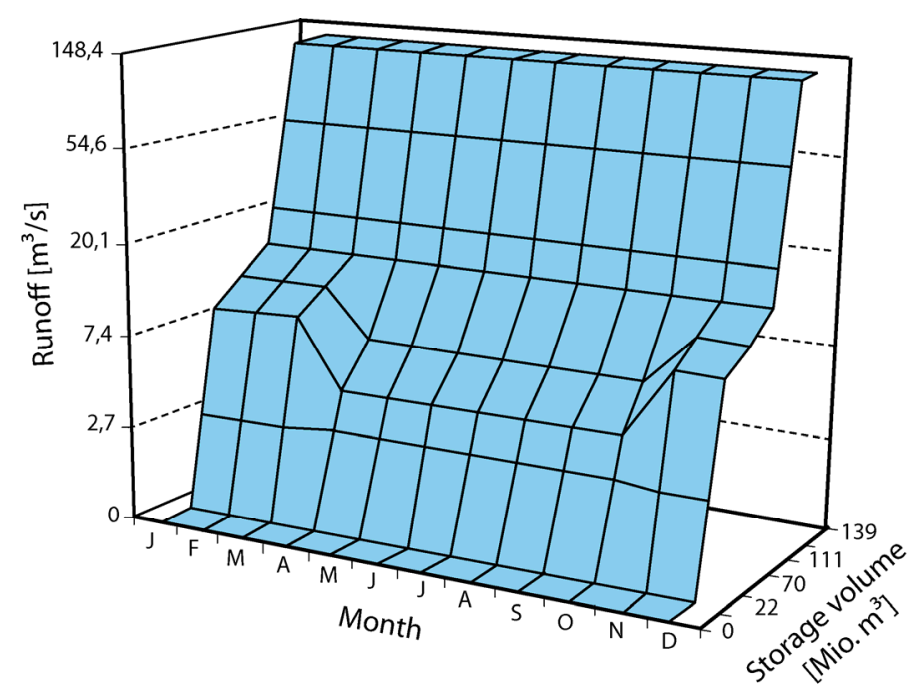

\subsection{The Hydropower Module}

All currently existing hydropower plants with a bottleneck capacity of more than $5 \mathrm{MW}$ (see Figure 2) are implemented in the hydropower module of PROMET to determine hydroelectric power generation. In general, hydroelectric power generation is based on potential and kinetic energy. Therefore the two most important parameters are runoff and hydraulic head. The capacity of each hydropower plant was calculated with an hourly resolution by the following equation: 


$$
P=\eta \cdot \rho \cdot Q \cdot g \cdot H
$$

where $P$ is the capacity (for a certain time period) $(\mathrm{kW}), \eta$ is the efficiency factor of a hydropower plant (-), $\rho$ is the density of water $\left(\mathrm{kg} \mathrm{m}^{-3}\right), g$ is the gravitational acceleration $\left(\mathrm{m} \mathrm{s}^{-2}\right), Q$ is the runoff $\left(\mathrm{m}^{3} \mathrm{~s}^{-1}\right)$ and $H$ is the hydraulic head $(\mathrm{m})$. The resulting capacity for each time step was then aggregated to mean daily, annual or decadal hydroelectric power generation values:

$$
E=P \cdot t
$$

where $E$ is the hydroelectric power generation (kWh), $P$ is the capacity (for a certain time period) $(\mathrm{kW})$ and $t$ is the time (h).

Each hydropower plant is located within the investigation area at a defined grid cell of $1 \mathrm{~km}^{2}$. Hence, for each hydropower plant the runoff $Q$ referred to the channel flow component is known for each time step. It is the only variable component of Equation (1) changing at each time step. Furthermore, for each of the 118 runoff-river power plants and the 22 reservoir power plants (cf. Figure 2), the following parameters were investigated and implemented individually: mean annual hydroelectric power generation, hydraulic head, efficiency factor, maximum capacity and starting year of operation of the power station. All data are based on the parameterization derived from the present.

The left side of Figure 4 illustrates schematically the relationship of capacity $P$ and runoff $Q$ for a runoff-river power plant. In general, an increase in channel flow leads to an increase in capacity until the maximum capacity $P_{\max }$ at the optimal runoff $Q_{o p t}$ value is reached. For most hydropower plants this point is similar to the maximum discharge of the turbines.

Figure 4. Relationship of capacity and runoff for runoff-river power plants (left) and for reservoir power plants (right) used in the model.
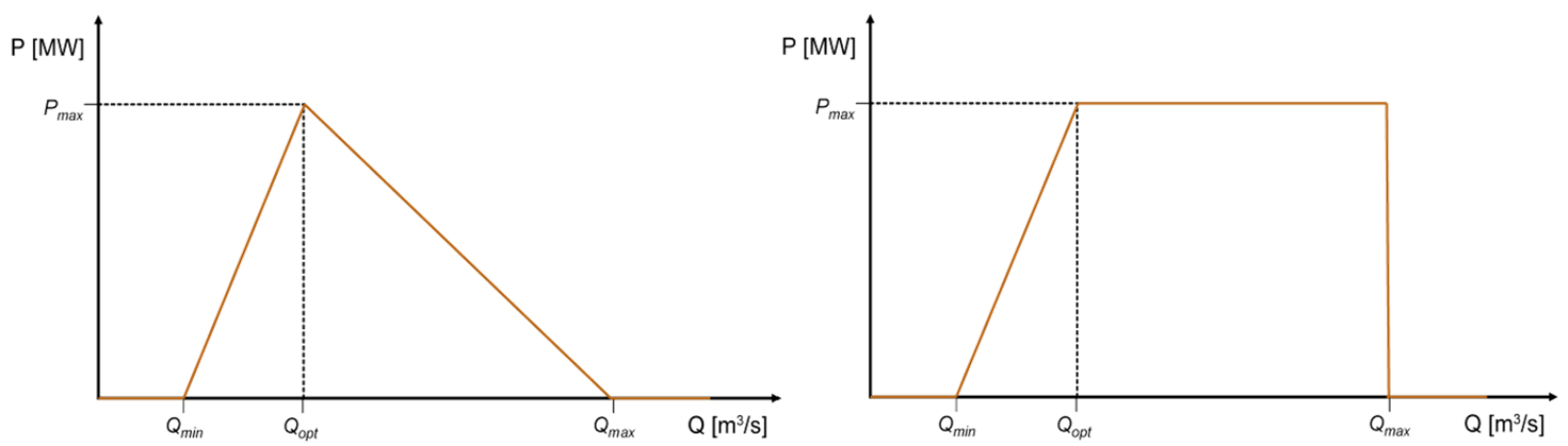

The energy generation starts at a minimum channel flow $Q_{\text {min }}$, which mainly is defined by low-flows and residual flow restrictions. During these situations no energy is produced because low-flows are often not discharged through the turbines. For the runoff-river power plants it is assumed that after achieving $P_{\max }$, the capacity decreases because more runoff leads to a rising downstream water level, which results in turn in a reduction of the hydraulic head. After reaching a set maximum channel flow $Q_{\max }$, the energy production is shut down taking restrictions of energy generation by extreme flood events into account. Overall, this scheme clearly shows that although the capacity is strongly related to the channel flow, low-flow and flood events also have a large impact on capacity. 
The relationship of capacity and runoff for a reservoir power plant is handled quite similarly and is shown schematically on the right of Figure 4 . The difference is that after reaching $Q_{o p t}, P_{\max }$ is held constant for a longer time, because a rising downstream water level has less influence. Furthermore, each reservoir power plant underlies monthly-based operating rules (see Section 3.1).

\subsection{Validation}

As the output of the hydropower module - the capacity or rather the hydroelectric power generation - is highly dependent on channel flow and extreme events like low-flows and floods, the hydrological model PROMET was validated using streamflow records at the outlet gauge Achleiten and several other gauges within the catchment on daily and annual time steps. The respective main validation results will be shortly outlined in the following; a detailed description is handled in Mauser and Bach [32]. The validation period for the runoff generated by PROMET is a 33-year model run covering the hydrological years (November-October) 1971 to 2003 with an hourly time step. This takes into account the standard climate period 1971-2000 with the extension of the extremely warm Central European Summer of 2003. The hourly runoff was generated for each $1 \mathrm{~km}^{2}$ pixel and aggregated to daily and annual values for further analysis. Firstly, the annual water balance was compared to the measured annual runoff at the outlet gauge at Achleiten (see Figure 5) through a linear regression analysis. Since the model should ideally reproduce the measured values the model $y=a \times x$ was taken as regression hypothesis. Both the slope and the coefficient of determination $R^{2}$ should be as close as possible to a value of 1 to ensure that the model reproduces the full dynamic of the measured data without any model bias [37]. The mean modelled runoff at the Achleiten outlet gauge $(598 \mathrm{~mm} / \mathrm{a})$ compares well with the measured runoff $(579 \mathrm{~mm} / \mathrm{a})$ [32]. Secondly, the validation of the short term runoff dynamics the measured versus modelled average daily runoff of the 33-years period was also compared at selected gauges in the watershed, by calculating slopes of linear regression lines forced through the origin, coefficients of determination and Nash-Sutcliffe efficiency coefficients [48]. The slopes of the regression lines detect systematic biases in the representation of the natural runoff dynamic by the model. The coefficients of determination give an indication of the amount of variance of the measured data, which is captured by the model simulation. The Nash-Sutcliffe efficiency coefficient compares the mean square error generated by a particular model simulation to the variance of the target output sequence. It is defined as:

$$
E=1-\frac{\sum_{t=1}^{T}\left(Q_{0}^{t}-Q_{m}^{t}\right)^{2}}{\sum_{t=1}^{T}\left(Q_{0}^{t}-\overline{Q_{o}}\right)^{2}}
$$

where $E$ is the Nash-Sutcliffe efficiency coefficient, $Q_{0}$, the measured runoff $\left(\mathrm{m}^{3} / \mathrm{s}\right), \overline{Q_{o}}$ the mean measured runoff $\left(\mathrm{m}^{3} / \mathrm{s}\right)$, the modelled runoff $Q_{m}\left(\mathrm{~m}^{3} / \mathrm{s}\right), T$ the time period and $t$ the selected time step. An efficiency of 1 corresponds to a perfect match of modelled discharge to the observed data. An efficiency of 0 indicates that the model predictions are as accurate as the mean of the observed data, whereas efficiency less than zero occur when the observed mean is a better predictor than the model. The closer the model efficiency is to 1 , the more accurately the model reproduces the data. This normalized measure is used to assess the predictive power of hydrological models; however it does not 
measure how good a model is in absolute terms. Additionally it should be mentioned that reliability of the Nash-Sutcliffe efficiency coefficient depends on the seasonality of the time series. The model performance for strongly seasonal time series, e.g., glacial regimes, can be overestimated. For time series with small fluctuations around the mean value, this coefficient is a rather good predictor [49].

Figure 5. Mean modelled water balance in the Upper Danube watershed during the period 1971 to 2003 and mean measured discharge at the Achleiten outlet gauge (based on Mauser and Bach [32]).

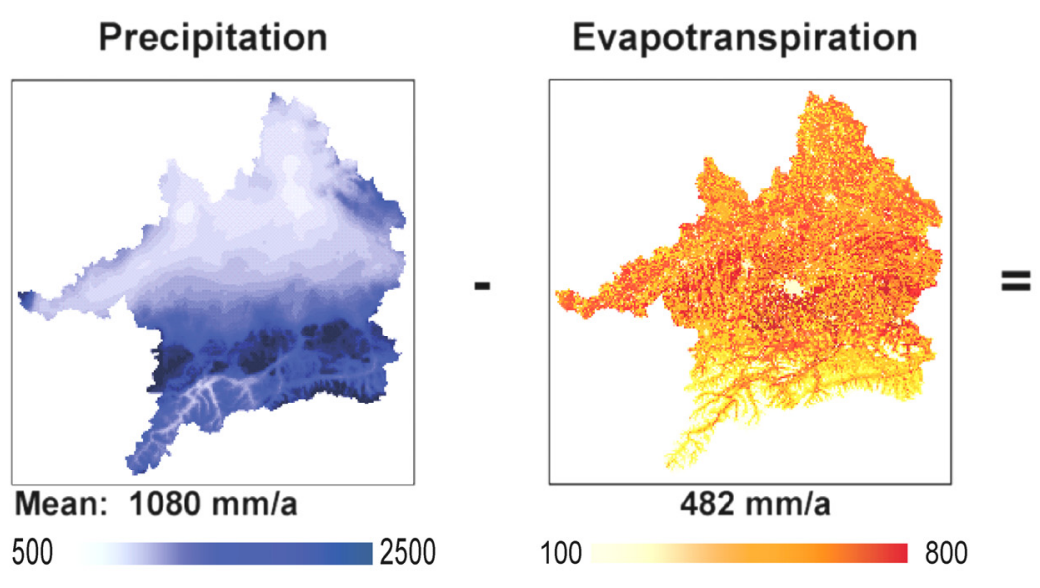

Mean Measured Discharge at Gauge Achleiten (1971-2003)

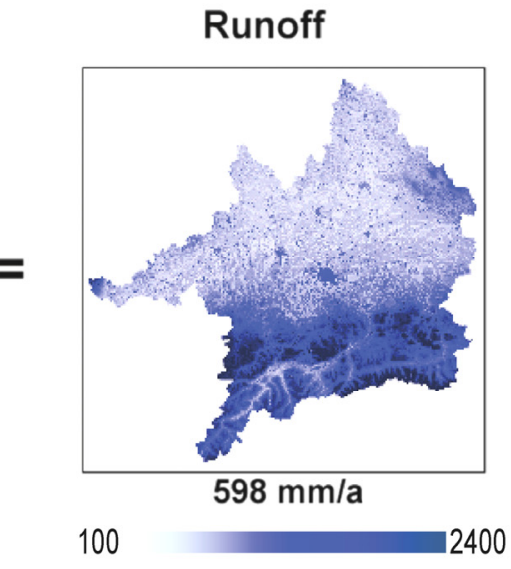

$579 \mathrm{~mm} / \mathrm{a}$

This analysis was executed at a broad range of different gauges of sub-watersheds at different places in the Upper Danube basin and is summarized together with the results from the analysis of the annual runoffs in Table 1. In general the slopes of the linear regression are close to 1 and the coefficients of determination are high, which indicate that the inter-annual and daily runoff dynamics are well captured by PROMET, both, at the outlet in Achleiten as well as in the sub-watersheds. The coefficient of determination is slightly higher for larger (sub-)watersheds. Accordingly, for the smallest selected watershed the $1 \mathrm{~km} \times 1 \mathrm{~km}$ resolution may not be sufficient for this model's settings and input data. Extreme events, namely low-flows and floods, have influence on the hydroelectric power generation of the hydropower module. The validation of low-flows and floods was carried out at the Achleiten outlet gauge for the same time period. The flood analysis considered the annual peak discharge, whereas the low-flow analysis considered the annual lowest 7-day average flow. Regarding the flood analysis a fairly stable relation was found, nevertheless an overestimation by $16 \%$ of the simulated values was shown because of neglecting inundations and dam breaks during very large floods. However, the simulated and measured low-flow frequency correlated very well. This also applies to the return periods of both extreme events [32]. In general, PROMET, which is not adjusted to observed runoff, is able to model the flow within the channel network and the extreme events low-flows and floods, by agreeing well up, to very well with measured values. Since the runoff is the only variable input of Equation (1) (see Section 3.2), the hydroelectric power generation is well displayed. The mean annual hydroelectric power generation $E_{m}$ calculated with PROMET has been validated for each power plant with the mean annual hydroelectric power generation $E_{o}$ published by the hydropower plant operators. 
Table 1. Statistical analysis by calculating slopes of linear regression lines, coefficients of determination and the Nash-Sutcliffe coefficient (only for the daily values) for the linear correlation between the modelled and measured annual and daily runoff of selected (sub-)watersheds in the Upper Danube basin in the period 1971-2003 (based on Mauser and Bach [32]).

\begin{tabular}{|c|c|c|c|c|c|c|c|}
\hline \multirow[b]{2}{*}{ Gauge name } & \multirow[b]{2}{*}{ River } & \multirow[b]{2}{*}{$\begin{array}{c}\text { Size of } \\
\text { (sub-) } \\
\text { watershed }\end{array}$} & \multicolumn{2}{|c|}{ Annual Values } & \multicolumn{3}{|c|}{ Daily Values } \\
\hline & & & $\begin{array}{c}\text { Slope of } \\
\text { linear } \\
\text { regression }\end{array}$ & $\begin{array}{l}\text { Coefficient of } \\
\text { determination }\end{array}$ & $\begin{array}{c}\text { Slope of } \\
\text { linear } \\
\text { regression }\end{array}$ & $\begin{array}{l}\text { Coefficient of } \\
\text { determination }\end{array}$ & $\begin{array}{c}\text { Nash-Sutcliffe } \\
\text { efficiency } \\
\text { coefficient }\end{array}$ \\
\hline Achleiten & Danube & $76,660 \mathrm{~km}^{2}$ & 1.05 & 0.93 & 1.03 & 0.87 & 0.84 \\
\hline Hofkirchen & Danube & $46,496 \mathrm{~km}^{2}$ & 1.12 & 0.93 & 1.11 & 0.87 & 0.81 \\
\hline Dillingen & Danube & $11,350 \mathrm{~km}^{2}$ & 1.14 & 0.93 & 1.13 & 0.84 & 0.72 \\
\hline Oberaudorf & Inn & $9715 \mathrm{~km}^{2}$ & 0.99 & 0.80 & 0.94 & 0.81 & 0.80 \\
\hline Plattling & Isar & $8435 \mathrm{~km}^{2}$ & 1.03 & 0.88 & 1.08 & 0.75 & 0.47 \\
\hline Laufen & Salzach & $6112 \mathrm{~km}^{2}$ & 0.93 & 0.85 & 0.86 & 0.85 & 0.80 \\
\hline Heitzenhofen & $\mathrm{Naab}$ & $5431 \mathrm{~km}^{2}$ & 1.01 & 0.86 & 0.99 & 0.78 & 0.79 \\
\hline Weilheim & Ammer & $607 \mathrm{~km}^{2}$ & 1.09 & 0.88 & 0.98 & 0.63 & 0.69 \\
\hline
\end{tabular}

This data was further confirmed by literature, websites and technical papers. The conducted validation of the mean annual values shows a very good correlation with a high coefficient of determination $R^{2}(0.99)$ on a long term basis (Figure 6).

Figure 6. Validation of the mean annual hydroelectric power generation by comparing the model output data $\left(E_{m}\right)$ with information from the hydropower plant operators $\left(E_{o}\right)$ for all considered hydropower plants in the Upper Danube basin for the time period 2000-2006.

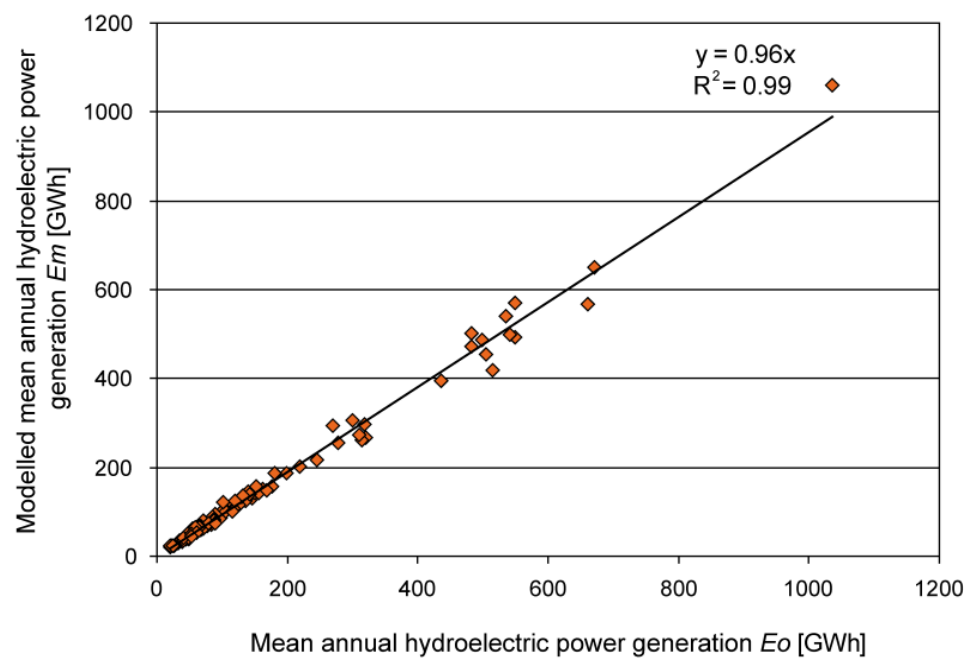

The time period 2000 to 2006 was chosen, because since 2000 nearly all hydropower plants integrated in the model had started with the energy production and the meteorological driver data for the model was available until 2006 (see Section 3.4). Regarding the relationship $E_{m} / E_{o}$ the mean (0.96) is close to the value 1 . The root mean square error $(0.08)$ and the variance $(0.01)$ have low values. This statistical analysis shows that the hydropower plants in the hydropower module are well reproduced for the mean annual values by the simulation. 
To further prove the hydroelectric power generation calculated with PROMET, daily production rates as published by the EEX energy stock exchange were consulted and used for validation of the model results. Validation on a finer temporal resolution was performed within the "HydroSense" service by VISTA Remote Sensing in Geosciences $\mathrm{GmbH}$, providing analyses and forecasts of hydropower generation based on PROMET calculation on an operational basis [50]. Based on a dense net of meteorological stations, provided by the private weather data service EWC, hourly and daily results of modeled runoff and hydropower production were created. As validation datasets, hourly published energy production of the EEX energy stock exchange [51] for the year 2010 was taken into consideration. These published datasets are based on a voluntary commitment of the main energy providers in Germany and Austria. Due to publishing structure, only the sum of energy production of 11 river-runoff power plants is provided by the EEX database. A comparison of the cumulated daily energy production for these 11 runoff-river power plants modelled with PROMET at the rivers Danube and Inn for the year 2010 is presented in Figure 7. Modelled daily production (red line) follows the published values (blue line) during the entire year and shows a very good correlation $(y=1.0057 x$; $\left.R^{2}=0.84\right)$.

A further analysis, comprising single power plants or reasonable hourly resolution, will be possible when more detailed information on energy production for river-runoff and reservoir hydropower, will be provided by the energy providers.

Figure 7. Total daily sum of 11 analysed runoff-river power plants located at the rivers Danube and Inn. Comparison of modelled HydroSense and published EEX hydroelectric power generation data.
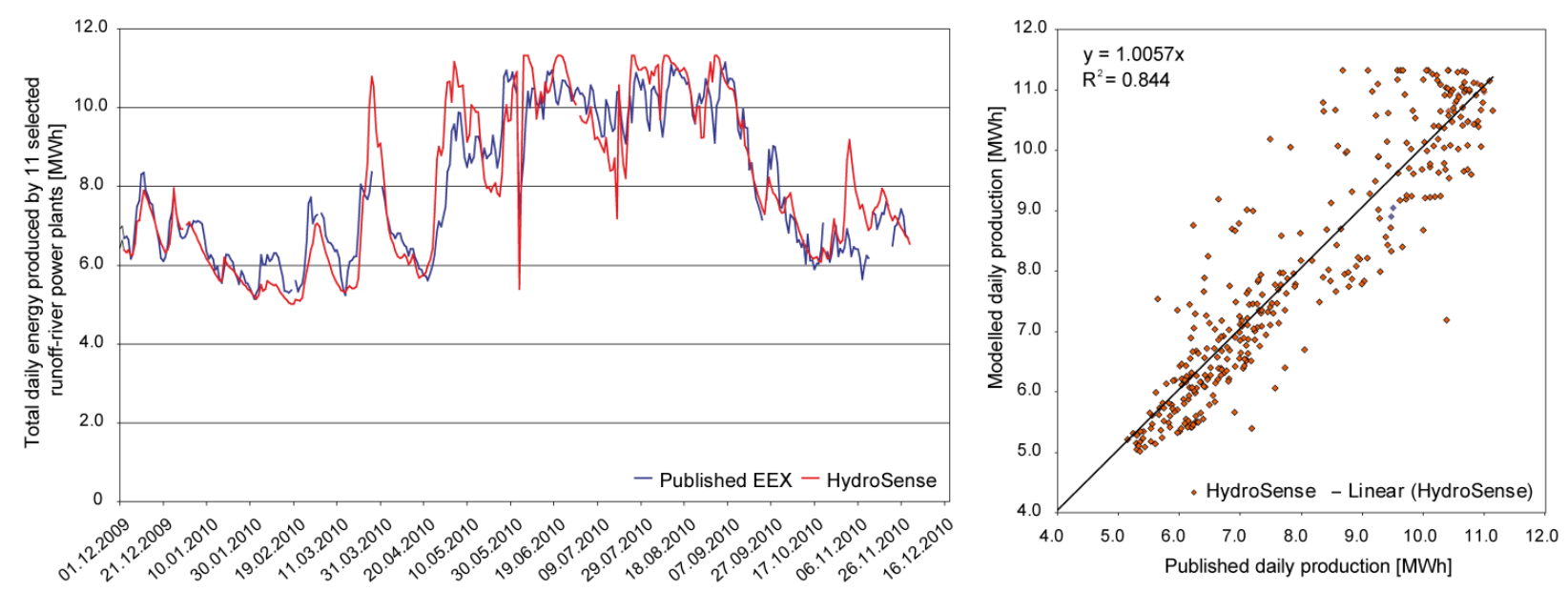

\subsection{Meteorological Input Data and Climate Trends}

The hydrological model PROMET requires meteorological driver data for each grid cell and each time step. To conduct past and future simulations, data for a past period (1960-2006) and for a future period (2011-2060) were set up during the GLOWA-Danube project. The generation and the specifications of the meteorological input data will be described in the following sections.

The past meteorological data set is derived from 277 climatologic stations from the standard network of the German (DWD) and Austrian (ZAMG) Weather Services. The investigated 
meteorological variables for each grid cell on a $1 \mathrm{~km}^{2}$ scale and an hourly time step are precipitation, air temperature, humidity, radiation, horizontal wind speed and air pressure. Therefore, firstly a cubic spline interpolation was used to generate hourly values out of the three standard daily records (7 a.m., 2 p.m. and 9 p.m.) of each meteorological station. Secondly, the spatial interpolation was carried out taking altitudinal gradients and a digital terrain model into account (see $[32,36])$.

The meteorological data set for the future was generated by using a stochastic climate generator [32,52], recombining the historical dataset, considering statistically different predefined climate trends. This generator is classified as a stochastic nearest neighbour climate generator similar to the approaches of Orlowsky et al. [53], Yates et al. [54], Buishand and Brandsma [55] and Young [56]. It produces a likely realisation of future climate and not synthetic weather data for regions with sparse data available like WGEN [57] or LARS-WG [58,59]. It is assumed that the annual course of a year can be decomposed into weeks represented by temperature means, precipitation sums and their covariance. This climate generator produces weekly sequences of temperature means, precipitation sums and their covariance out of historic data and reassembles them randomly by an underlying climate trend on temperature and precipitation for the future time period. The outputs are new, synthetic time series with the same temporal and spatial resolution as the input data, whereby the physical relations between the meteorological variables are restored. At present stage, future precipitation can be better represented with the climate generator than with most direct regional climate model (RCM) simulations. Another advantage of the climate generator is that the future scenario climate data need no bias correction because it uses the change signal and not RCM data series directly. It should be kept in mind, however, that the general statistical relationship of temperature and precipitation is assumed not to change in future [32]. Regarding the limits of the climate change generator, e.g., a future change in weather patterns, however, can not be considered appropriately with this tool.

To identify possible future changes and to cover a plausible range of uncertainties in regional climate development, 16 climate scenarios, resulting from different ensemble outputs of the stochastic climate generator, were taken as meteorological drivers for the period 2011-2060. All climate scenarios are based on the global IPCC-SRES-A1B emission scenario, which shows a mean development of greenhouse gas emissions due to mid-line economic growth [1], and are part of four regional climate trends. For each of the four trends, four climate scenarios have been selected on statistical criteria. They follow different approaches and are named thereafter IPCC regional, REMO regional MM5 regional, and Extrapolation. The IPCC regional climate trend is based on the results from 21 global climate models for Central Europe presented in the latest IPCC report [1]. The REMO regional trend underlies the application of the RCM REMO driven by ECHAM5 [60], which is applied in several studies in this region [8,21,60-62]. Among other RCMs, REMO represents a moderate temperature and precipitation development $[63,64]$. Several RCMs underestimate for example the summer drying especially in the Danube region. REMO, however, shows a very modest bias [64]. To cover a range of uncertainties a second RCM trend, the MM5 regional trend, which is based on the application of the regional climate model MM5 and is also driven by ECHAM5 [65], was applied. The background of the Extrapolation trend is the analysis of temperature and precipitation trends of historic climate stations data of the German (DWD) and Austrian (ZAMG) weather services, analysed by Reiter et al. [66].

To show the characteristic development of the meteorological input data, Table 2 gives an overview of the temperature and precipitation changes between 1990 and 2100 regarding the four climate trends 
considering annual and semi-annual summer (May-October) and winter (November-April) periods. For the annual values all trends show a clear increase in temperature and a varying decline in precipitation until 2100. In general, the IPCC regional trend is the weakest, followed by the rather moderate trends MM5 regional and REMO regional. The Extrapolation trend is the most severe one. For all four trends temperature increase results in less annual precipitation with a clear decrease in summer and a slighter increase in winter. Thereby, comparing the middle trends, REMO regional shows a slightly higher decrease in summer and a smaller increase in winter than MM5 regional.

Table 2. Temperature increase (K) and precipitation changes (\%) between 1990 and 2100 regarding the four climate trends IPCC regional, MM5 regional, REMO regional and Extrapolation.

\begin{tabular}{|c|c|c|c|c|}
\hline \multirow{2}{*}{ Climate Trend } & Temperature Increase (K) & \multicolumn{3}{|c|}{ Precipitation Changes (\%) } \\
\cline { 2 - 5 } & Annual & Annual & $\begin{array}{c}\text { Winter } \\
\text { (November-April) }\end{array}$ & $\begin{array}{c}\text { Summer } \\
\text { (May-October) }\end{array}$ \\
\hline IPCC regional & +3.3 & -4.4 & +2.1 & -10.2 \\
MM5 regional & +4.7 & -3.5 & +10.1 & -14.6 \\
REMO regional & +5.2 & -12.6 & +7.3 & -16.6 \\
Extrapolation & +5.2 & -16.4 & +9.0 & -30.7 \\
\hline
\end{tabular}

As shown in Section 4.1, the temperature and precipitation changes of each trend trigger in turn by a more or less extent, changes in runoff, the hydrological storage and thereafter also in hydroelectric power generation.

\section{Results and Discussion of Future Scenarios}

The results, analysed in the following chapters, display a possible range of future development of the hydroelectric power generation under a changing meteorological and hydrological situation in the Upper Danube basin for the next 50 years. The applied climate change scenario conditions are based on the global IPCC-SRES-A1B emission scenario and consider uncertainties in the climate projections. To cover a near and a far future time period, the two decades 2021-2030 and 2051-2060 are regarded, which are compared with the reference decade 1991-2000. These three decades show future changes in equal time steps of 30 years. In general, the development of the hydroelectric power generation is highly correlated with the meteorological development of the specific climate trends shown in Table 2 and the triggered hydrological changes in runoff, evaporation, the snow and ice storage and the occurrence of the extreme events low-flows and floods addressed in Section 4.1. The mean annual and semi-annual summer and winter development of the hydroelectric power generation of all hydropower plants in the investigation area are shown in Section 4.2. To specify regional differences, the development of the mean monthly course of the hydroelectric power generation of three hydropower plants in hydrologically different parts of the investigation area are analysed in Section 4.3. Further, the future regional developments of the main runoff components rain, snow- and ice-melt and their impact on the hydroelectric power generation are discussed. 


\subsection{Future Meteorological and Hydrological Development in the Upper Danube Basin}

Besides a clear temperature increase, the water resources in the Upper Danube basin will be affected by climate change. Table 3 gives an overview on changes of important meteorological and hydrological variables for the four climate trends considering the two future decades 2021-2030 and 2051-2060 compared with the reference decade 1991-2000.

Table 3. Development of the meteorological and hydrological situation in the Upper Danube basin for the future decades 2021-2030 and 2051-2060 compared with the reference decade 1991-2000 considering the four climate trends IPCC regional, MM5 regional, REMO regional and Extrapolation.

\begin{tabular}{|c|c|c|c|c|c|c|}
\hline \multirow{2}{*}{$\begin{array}{l}\text { Meteorological and } \\
\text { hydrological variables }\end{array}$} & \multirow{2}{*}{ 1991-2000 } & \multirow{2}{*}{ Climate trend } & \multicolumn{2}{|c|}{ 2021-2030 } & \multicolumn{2}{|c|}{ 2051-2060 } \\
\hline & & & Av. & $\Delta$ & Av. & $\Delta$ \\
\hline \multirow{4}{*}{$\begin{array}{l}\text { Mean annual air } \\
\text { temperature }\left({ }^{\circ} \mathrm{C}\right)\end{array}$} & \multirow{4}{*}{7.01} & IPCC & 8.04 & +1.03 & 9.18 & +2.17 \\
\hline & & MM5 & 8.26 & +1.25 & 9.70 & +2.69 \\
\hline & & REMO & 8.43 & +1.42 & 10.06 & +3.05 \\
\hline & & Extrapolation & 8.08 & +1.07 & 9.75 & +2.74 \\
\hline \multirow{4}{*}{$\begin{array}{l}\text { Mean annual precipitation } \\
\text { sum }(\mathrm{mm})\end{array}$} & \multirow{4}{*}{1060} & IPCC & 1071 & $+1 \%$ & 1053 & $-1 \%$ \\
\hline & & MM5 & 1052 & $-1 \%$ & 1055 & $0 \%$ \\
\hline & & REMO & 1020 & $-4 \%$ & 1013 & $-4 \%$ \\
\hline & & Extrapolation & 1061 & $0 \%$ & 959 & $-10 \%$ \\
\hline \multirow{4}{*}{$\begin{array}{l}\text { Mean annual snow } \\
\text { precipitation fraction }(\%)\end{array}$} & \multirow{4}{*}{22} & IPCC & 21 & -1 & 18 & -5 \\
\hline & & MM5 & 20 & -2 & 17 & -5 \\
\hline & & REMO & 21 & -2 & 13 & -10 \\
\hline & & Extrapolation & 22 & 0 & 16 & -6 \\
\hline \multirow{4}{*}{$\begin{array}{l}\text { Mean annual } \\
\text { evapotranspiration }(\mathrm{mm})\end{array}$} & \multirow{4}{*}{416} & IPCC & 445 & $+7 \%$ & 459 & $+10 \%$ \\
\hline & & MM5 & 415 & $0 \%$ & 429 & $+3 \%$ \\
\hline & & REMO & 419 & $+1 \%$ & 442 & $+6 \%$ \\
\hline & & Extrapolation & 426 & $+2 \%$ & 433 & $+4 \%$ \\
\hline \multirow{4}{*}{$\begin{array}{l}\text { Mean runoff at Achleiten } \\
\text { outlet gauge }\left(\mathrm{m}^{3} / \mathrm{s}\right)\end{array}$} & \multirow{4}{*}{1480} & IPCC & 1568 & $+6 \%$ & 1408 & $-5 \%$ \\
\hline & & MM5 & 1482 & $0 \%$ & 1444 & $-2 \%$ \\
\hline & & REMO & 1397 & $-6 \%$ & 1315 & $-11 \%$ \\
\hline & & Extrapolation & 1546 & $+4 \%$ & 1286 & $-13 \%$ \\
\hline \multirow{4}{*}{$\begin{array}{l}\text { Water stored as glacier ice } \\
\left(10^{6} \mathrm{~m}^{3}\right)\end{array}$} & \multirow{4}{*}{16,591} & IPCC & 3979 & $-76 \%$ & 292 & $-98 \%$ \\
\hline & & MM5 & 4044 & $-76 \%$ & 199 & $-99 \%$ \\
\hline & & REMO & 3833 & $-77 \%$ & 188 & $-99 \%$ \\
\hline & & Extrapolation & 4157 & $-75 \%$ & 214 & $-99 \%$ \\
\hline \multirow{4}{*}{$\begin{array}{l}\text { Average amount of } \\
\text { snowmelt }(\mathrm{mm})\end{array}$} & \multirow{4}{*}{332} & IPCC & 319 & $-4 \%$ & 271 & $-18 \%$ \\
\hline & & MM5 & 306 & $-8 \%$ & 259 & $-22 \%$ \\
\hline & & REMO & 297 & $-11 \%$ & 224 & $-33 \%$ \\
\hline & & Extrapolation & 339 & $+2 \%$ & 270 & $-19 \%$ \\
\hline
\end{tabular}

For the mean of each decade Table 3 shows values for mean annual temperature and mean annual precipitation sums as well as values for the mean annual snow precipitation fraction, mean annual evapotranspiration, mean runoff at the Achleiten gauge, water stored as glaciers and the average 
amount of snowmelt. Depending on each climate trend, temperature increase causes a more or less severe rise in evapotranspiration, a negative trend in precipitation with a clear reduction of the snow precipitation fraction and a reduction of the mean annual runoff at the Achleiten gauge until 2060. According to the trend analysis based on Mann [67] and Kendall [68] the future trends of the annual runoff is significant for the average of REMO (significant on the 0.01 level of signification), MM5 (significant on the 0.001 level of signification) and Extrapolation (significant on the 0.1 level of signification), whereas for the IPCC scenario outputs no significant trend was detected. Together with the changes in precipitation, future water availability will be reduced particularly along the northern rim of the Alps, where precipitation will decrease and evapotranspiration increase because of a longer growing season as shown exemplarily for the rather medium climate trend REMO regional (see Figure 8). In contrast, in the northern part of the watershed a slight increase of water availability is partly modelled, which is due to small changes in the total amount of precipitation and a reduction of evapotranspiration.

Figure 8. Difference of the water balance between the two periods 2036-2060 and 1971-2000 in the Upper Danube basin. This calculation is based on the trend REMO regional (based on Prasch and Mauser [37]).

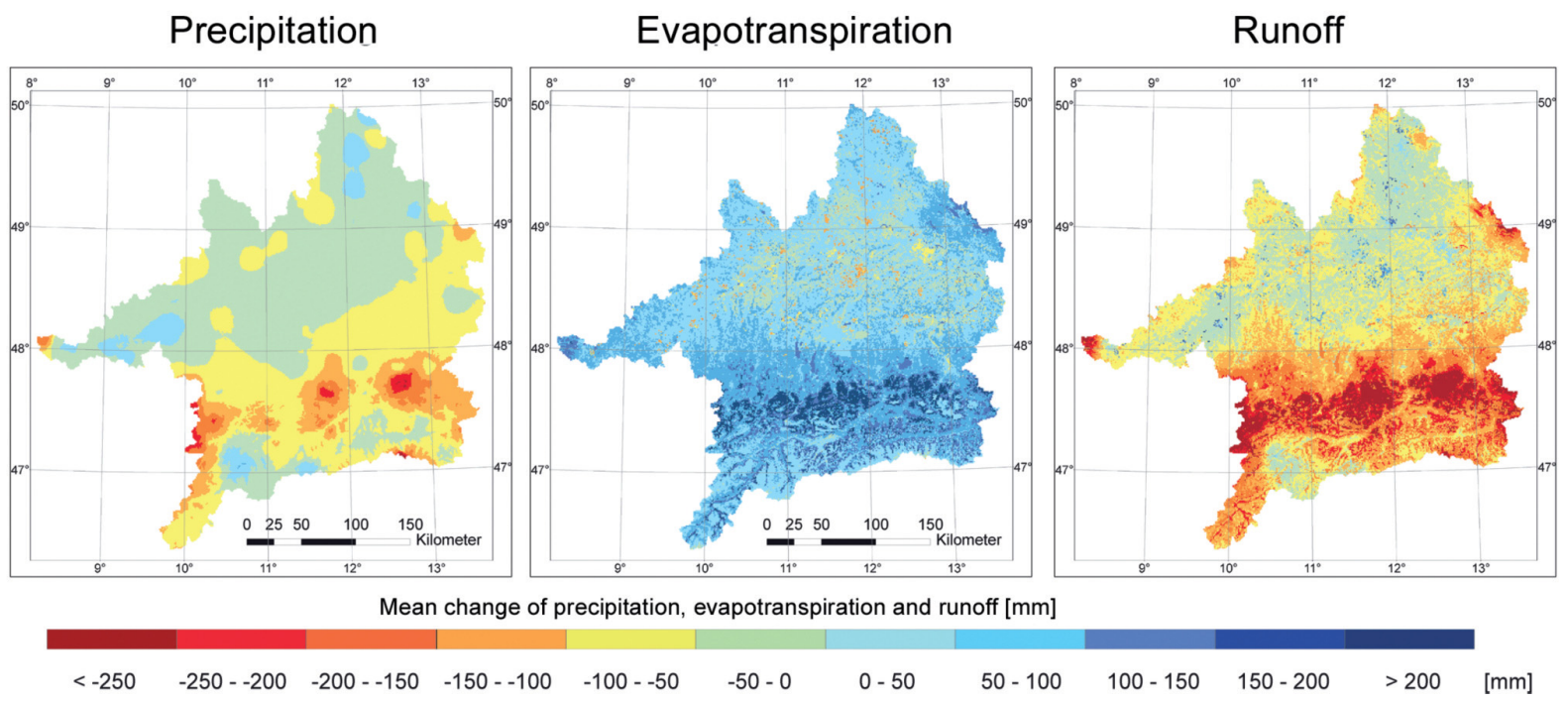

Regarding the decades between 1961 and 2060, the mean seasonal course of runoff at the Achleiten outlet gauge indicates a shift of the mean monthly runoff peak from summer to spring, exemplarily shown for the climate trend REMO regional (see Figure 9). This shift is attributed to the reduction of the snow storage and an earlier snow-melt in the year as well as an increase in evapotranspiration and less precipitation during summer. However, the seasonal course of precipitation with its maximum during summer will flatten, but will not change remarkably [37]. 
Figure 9. Decadal course of monthly precipitation in the Upper Danube basin and discharge from 1961 to 2060 at the Achleiten outlet gauge. This calculation is based on the trend REMO regional (based on Prasch and Mauser [37]).
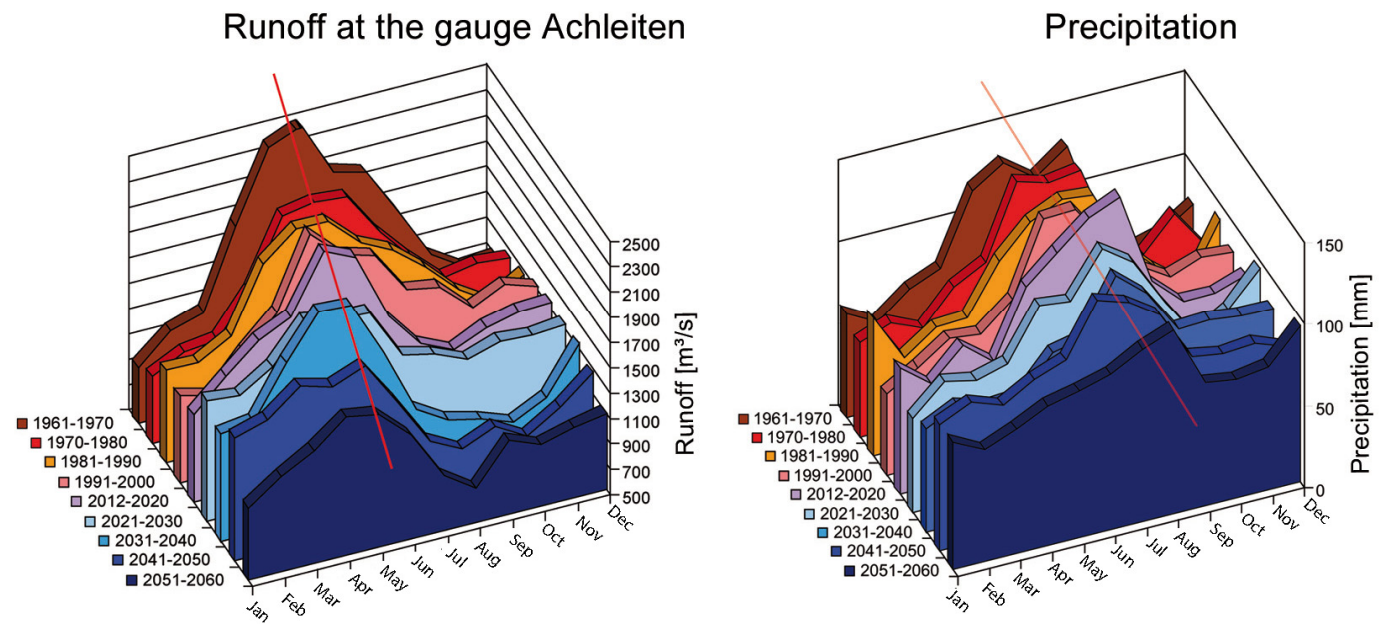

The future low-flow conditions show a remarkable change in the low-flow regime of the Danube as well as severe changes in peak low-flow and its frequency of occurrence [32,69]. Low-flow will decrease distinctly under all trends at the Achleiten outlet gauge until 2060. However in contrast to a reduction along the Upper Danube River, an increase of low-flow is modelled in the alpine valleys. Reasons are a transformation of snowfall into rainfall and melting glaciers. Regarding the development of flood peaks, an increase is indicated in the alpine valleys and head-watersheds. In the other parts of the Upper Danube basin, the flood peaks stay almost stable. This again can be explained by changes of the mean annual snowfall fraction compared with total mean annual precipitation [37].

\subsection{Hydropower Development in the Upper Danube Basin}

The development of the hydroelectric power generation is visualized in Figure 10 for annual and semi-annual summer (May-October) and winter (November-April) values for the time period 2011-2060. To reduce uncertainties of single climate scenarios and to get a clearer picture about the development for each trend, the means of the model outputs of the four climate scenarios were taken. Further, to cover a plausible range of all 16 climate scenarios, the minima and maxima values of the climate scenarios were considered. Table 4 complements the analysis by showing explicit values of the development in percent for the future decades 2021-2030 and 2051-2060 based on the reference period 1991-2000. For the past decade, the total mean annual hydroelectric power generation of all considered hydropower plants in the Upper Danube basin reached $17.6 \mathrm{TWh}$, whereof about 70\% were produced through runoff-river power plants and about 30\% through reservoir hydropower plants. The energy production for the mean summer values accounted to $11.1 \mathrm{TWh}$ and for the mean winter values $6.5 \mathrm{TWh}$. 
Figure 10. Development of hydroelectric power generation in the Upper Danube basin of annual and semi-annual summer and winter values for the time period 2011-2060 considering the means of the four climate trends IPCC regional, MM5 regional, REMO regional and Extrapolation and minima and maxima of all 16 climate scenarios.

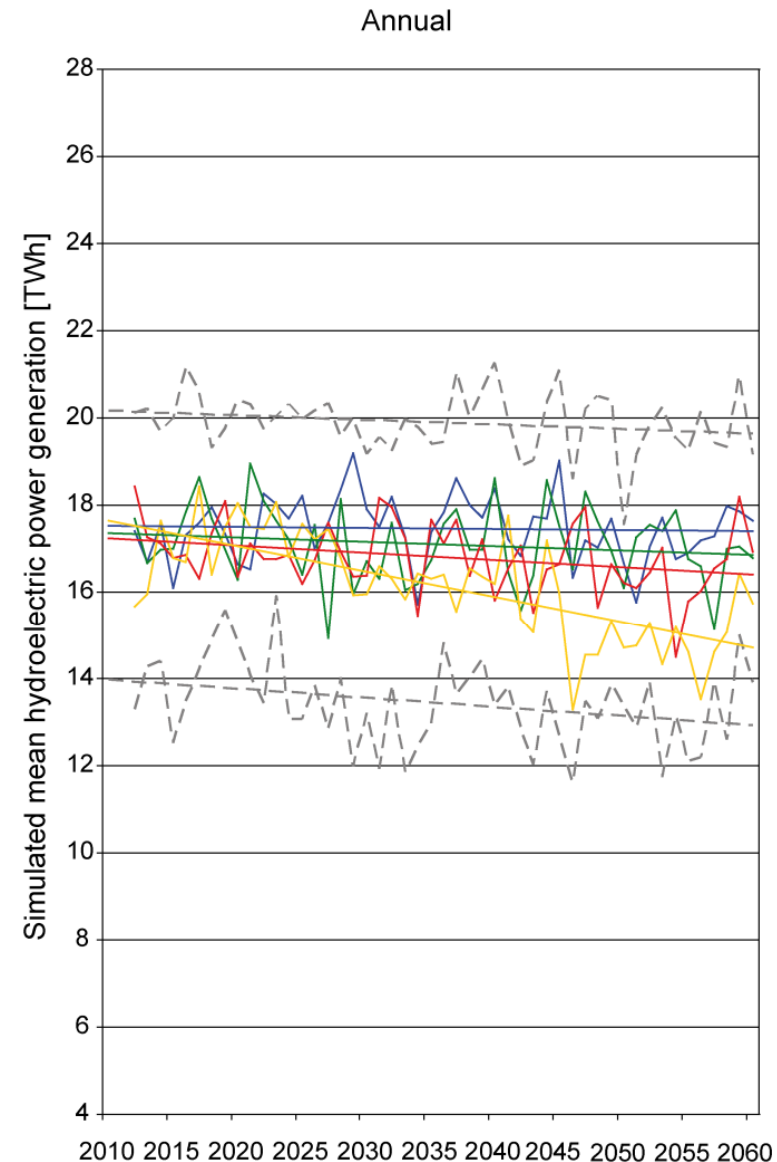

— IPCC regional _ MM5 regional
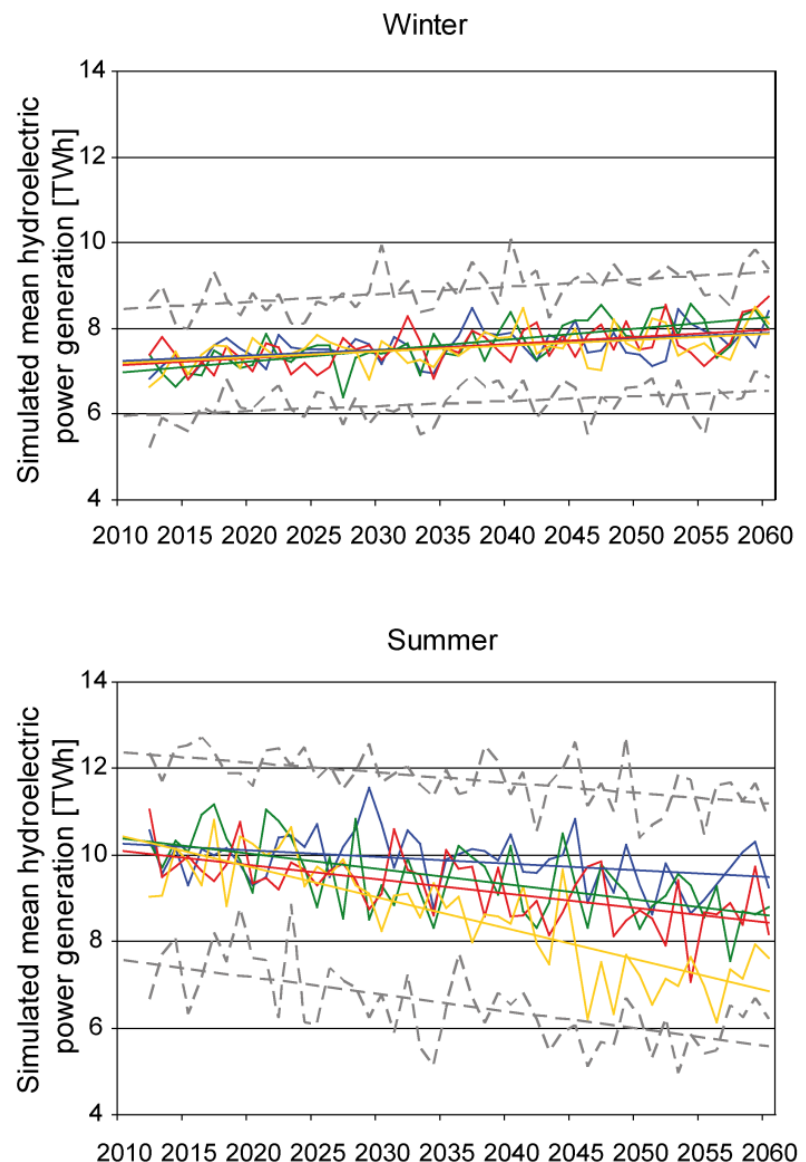

20102015202020252030203520402045205020552060

\subsubsection{Development of Annual Production}

Regarding the development of the mean annual hydroelectric power generation in the Upper Danube basin in Figure 10, a general decline was determined for all climate trends and the minima and maxima values until 2060. Thereby, Table 4 shows that the IPCC regional trend is rather moderate, with a decline of $2 \%$ until the future decade 2051-2060. However, for the nearer future decade 2021-2030 a slight increase of 2\% was modelled. MM5 regional shows a slight decrease of 3\% for the first future decade and of $4 \%$ for the second future decade. Hydroelectric power generation simulated with REMO regional can be classified in the middle range with a decline by $5 \%$ for the first future decade and $7 \%$ for the second decade. Extrapolation displays the most severe values with a decrease of $15 \%$ until 2060, but indicates only a slight decrease of 3\% until 2030. In general, under these climate trends the mean annual hydroelectric power generation will decline to a range of 17 to $18 \mathrm{TWh}$ in 2021-2030, respectively of 15 to 17 TWh in 2051-2060. These results show a close correlation with the development of the precipitation situation shown in Section 3.4 for each trend, whereby IPCC regional shows the lowest annual decrease, followed by MM5 regional and REMO regional and the 
severest annual decline with Extrapolation. Besides the decrease in precipitation, the decline of the mean annual hydroelectric power generation is caused mostly by an increase in mean annual evapotranspiration and a decrease in mean annual runoff as shown in Section 4.1.

Table 4. Development of hydroelectric power generation in the Upper Danube basin by annual and semi-annual summer and winter values for the future decades 2021-2030 and 2051-2060 compared with the reference decade 1991-2000 considering the four climate trends IPCC regional, MM5 regional, REMO regional and Extrapolation.

\begin{tabular}{|c|c|c|c|c|c|c|}
\hline & & \multirow{2}{*}{$\begin{array}{c}\text { 1991-2000 } \\
\text { (TWh) }\end{array}$} & \multicolumn{2}{|c|}{ 2021-2030 } & \multicolumn{2}{|c|}{ 2051-2060 } \\
\hline & & & (TWh) & $(\%)$ & (TWh) & $(\%)$ \\
\hline \multirow{5}{*}{ Annual } & Reference & 17.6 & - & - & - & - \\
\hline & IPCC regional & - & 17.9 & +1.5 & 17.2 & -2.2 \\
\hline & MM5 regional & - & 17.2 & -2.5 & 16.9 & -3.8 \\
\hline & REMO regional & - & 16.8 & -4.7 & 16.4 & -6.7 \\
\hline & Extrapolation & - & 17.1 & -3.0 & 15.0 & -15.0 \\
\hline \multirow{5}{*}{ Summer } & Reference & 11.1 & - & - & - & - \\
\hline & IPCC regional & & 10.4 & -6.4 & 9.4 & -15.3 \\
\hline & MM5 regional & & 9.8 & -11.7 & 8.8 & -20.5 \\
\hline & REMO regional & & 9.4 & -15.1 & 8.5 & -23.0 \\
\hline & Extrapolation & & 9.6 & -13.5 & 7.1 & -35.6 \\
\hline \multirow{5}{*}{ Winter } & Reference & 6.5 & - & - & - & - \\
\hline & IPCC regional & - & 7.5 & +15.0 & 7.8 & +19.9 \\
\hline & MM5 regional & - & 7.4 & +12.3 & 8.1 & +24.5 \\
\hline & REMO regional & - & 7.4 & +12.7 & 7.9 & +21.0 \\
\hline & Extrapolation & - & 7.5 & +14.7 & 7.8 & +19.8 \\
\hline
\end{tabular}

\subsubsection{Development in Winter}

Currently the winter energy production in the Upper Danube basin is lower than in summer. However, as illustrated in Figure 10, all four climate trends show an increase of the hydroelectric power generation in the Upper Danube basin for the winter periods until 2060. The main reason for this development is the general increase of precipitation in winter (Section 3.4) and a decline in solid precipitation and thereby snow storage, leading to more runoff. As a consequence, the future alpine low-flow situation in winter will be less severe leading in turn to a further increase of hydroelectric power generation. Furthermore, the range of the minima und maxima energy production in winter is lower indicating an inferior natural variability than in summer. For both future decades, all four trends show, as listed in Table 4, a similar increase by $20 \%$ (IPCC regional and Extrapolation), 21\% (REMO regional) and 25\% (MM5 regional) until 2060; whereby the latter originates in the highest increase in winter precipitation. In general, compared with the $6.5 \mathrm{TWh}$ of the reference decade, the hydroelectric power generation for all hydropower plants is said to increase in winter between 7.4 to $7.5 \mathrm{TWh}$ in the decade 2021-2030, and 7.8 to 8.1 TWh in the decade 2051-2060. This development leads to a significant increase of hydroelectric power generation during winter. 


\subsubsection{Development in Summer}

Contrary to the winter development, for the summer periods, a decline of hydroelectric power generation in the Upper Danube basin is displayed in Figure 10 for all trends until 2060. This is mainly triggered by a decrease in summer precipitation as shown in Section 3.4, a decline in snow- and ice-melting rates and an increase in evapotranspiration. Moreover, low-flow will decrease remarkably under all trends at the Achleiten outlet gauge until 2060, leading to more losses in hydroelectric power generation. Besides, the minima and maxima values delineate a big range of possible summer values of the single climate scenarios, indicating a high natural variability. The IPCC regional trend is again rather moderate, the trends MM5 regional and REMO regional lie in the middle and the trend Extrapolation at the upper boundary. Until 2060 the trends decline with a range between 15\% (IPCC regional) and 36\% (Extrapolation) (see Table 4). The more moderate trends MM5 regional and REMO regional indicate a decrease by 21 and 23\%, respectively. As an exception, during 2021-2030, the results of the trend REMO regional is slightly more severe than of the trend Extrapolation. The reason for this is that the summer decline in precipitation does not increase linearly. For the trend Extrapolation, e.g., the development is more pronounced in the second scenario period. Whereas the summer energy generation was 11.1 TWh in the reference decade, the hydroelectric power generation for all hydropower plants in the investigation area declines from 9.4 to $10.4 \mathrm{TWh}$ in the decade 2021-2030, and from 7.1 to 9.4 TWh in the decade 2051-2060. This indicates obvious future energy production losses during summer.

\subsubsection{Development of the Summer and Winter Fraction}

Table 5 lists the development of the summer and winter fractions of hydroelectric power generation in the Upper Danube basin for the reference decade 1991-2000 and the two future decades 2021-2030 and 2051-2060. In 1991-2000 the ratio of summer to winter production was 63 to $37 \%$. Whilst the past energy production was considerable higher in summer than in winter, the summer and winter fractions become more inter-annually equalized until 2060. In 2021-2030 the ratio shows already a range of 56 to $58 \%$ for the summer production and 42 to $44 \%$ for the winter production depending on the climate trends. At the end of the simulation period the values of the summer and winter periods will be quite similar with summer production percentages of 47 to $55 \%$ and winter percentages of 45 to $53 \%$ depending on the climate trends. The trend Extrapolation even indicates a higher winter than summer production for the decade 2051-2060. This means that the semi-annual hydroelectric power generation will be more balanced in the future.

In general, the future development of the mean annual hydroelectric power generation of all hydropower plants in the Upper Danube basin indicates a decline with its severity depending on the respective climate trend. Whilst the summer values experience a decrease with a large range of minima and maxima values of the single scenarios, the winter values increase with a low variability until 2060. 
Table 5. Development of the mean semi-annual summer and winter energy production fraction (\%) based on the mean annual hydroelectric power generation in the Upper Danube basin for the decades 1991-2000, 2021-2030 and 2051-2060 considering the four climate trends IPCC regional, MM5 regional, REMO regional and Extrapolation.

\begin{tabular}{|c|c|c|c|c|c|c|}
\cline { 2 - 7 } \multicolumn{1}{c|}{} & \multicolumn{2}{c|}{$\mathbf{1 9 9 1 - 2 0 0 0}$} & \multicolumn{2}{c|}{$\mathbf{2 0 2 1 - 2 0 3 0}$} & \multicolumn{2}{c|}{$\mathbf{2 0 5 1 - 2 0 6 0}$} \\
\cline { 2 - 7 } \multicolumn{1}{c|}{} & Summer & Winter & Summer & Winter & Summer & Winter \\
\hline Reference & 63.1 & 36.9 & & & & \\
IPCC regional & & & 58.1 & 41.9 & 54.7 & 45.3 \\
MM5 regional & & & 57.0 & 43.0 & 52.1 & 47.9 \\
REMO regional & & & 56.0 & 44.0 & 51.8 & 48.2 \\
Extrapolation & & & 56.1 & 43.9 & 47.3 & 52.7 \\
\hline
\end{tabular}

\subsection{Regional Differences within the Upper Danube Basin}

In this Section different regional developments within the Upper Danube basin are analysed. To work out such regional differences, three hydropower plants were chosen, situated in hydrologically different parts, which diverge in their degree of alpine character: Donauwoerth (Danube), Wasserburg (Inn) and Kaunertal (Gepatsch reservoir) (see pink circles in Figure 2). After a short description of their main hydrological and hydroelectric characteristics, the past and future contributions of the runoff components rain, snow- and ice-melt are shown. This leads to a discussion on their regional differences and their inter-annual development. Hence, the development of the three demonstrated hydropower plants should also represent the development of others with similar regional characteristics.

Table 6. Main hydroelectric characteristics of the hydropower plants (a) Donauwoerth (Danube), (b) Wasserburg (Inn) and (c) Kaunertal (Gepatsch reservoir).

\begin{tabular}{|l|l|l|l|}
\cline { 2 - 4 } \multicolumn{1}{c|}{} & (a) Donauwoerth & (b) Wasserburg & (c) Kaunertal \\
\hline Location at river/reservoir & river Danube & river Inn & $\begin{array}{l}\text { Gepatsch reservoir, filled by the } \\
\text { stream Faggenbach and several } \\
\text { water transfers }\end{array}$ \\
\hline Geogr. coordinates & $\begin{array}{l}\text { E } 10.77^{\circ}, \\
\text { N } 48.70^{\circ}\end{array}$ & $\begin{array}{l}\text { E } 12.22^{\circ}, \\
\text { N } 48.06^{\circ}\end{array}$ & E $10.74^{\circ}, \mathrm{N}_{4} 46.96^{\circ}$ \\
\hline Type of hydropower plant & $\begin{array}{l}\text { runoff-river } \\
\text { power plant }\end{array}$ & $\begin{array}{l}\text { runoff-river } \\
\text { power plant }\end{array}$ & reservoir power plant \\
\hline Start year of operation & 1984 & 1938 & 1964 \\
\hline Mean hydraulic head & $5.5 \mathrm{~m}$ & $7.0 \mathrm{~m}$ & $844.0 \mathrm{~m}$ \\
\hline Maximum turbine discharge & $200 \mathrm{~m}^{3} / \mathrm{s}$ & $465 \mathrm{~m}^{3} / \mathrm{s} *$ & $54 \mathrm{~m}^{3} / \mathrm{s}$ \\
\hline Maximum capacity & $8.5 \mathrm{MW}$ & $24 \mathrm{MW}^{*}$ & $370 \mathrm{MW}$ \\
\hline $\begin{array}{l}\text { Mean annual hydroelectric } \\
\text { power generation }\end{array}$ & $54.8 \mathrm{GWh}$ & $148.3 \mathrm{GWh} *$ & $661.0 \mathrm{GWh}$ \\
\hline Data base & {$[70,71]$} & {$[70,72]$} & {$[73]$} \\
\hline
\end{tabular}

* In 2009 the maximum turbine discharge and the maximum capacity of the hydropower plant Wasserburg (Inn) was increased by installing a new turbine in one section. This achieved an additional mean annual hydroelectric power generation of $12.6 \mathrm{GWh}$ [72]. However, this change was not considered for the future simulations. So the same constellation than in the reference period 1991-2000 was assumed for a better comparison. 


\subsubsection{Hydrological and Hydroelectric Characteristics}

The three hydropower plants cover typical hydrological differences with more or less alpine influence. Table 6 gives an overview about the main hydroelectric characteristics.

The three facilities are briefly described hereafter:

(1) The Donauwoerth runoff-river power plant is situated at the upper part of the river Danube with a catchment area of $12,693 \mathrm{~km}^{2}$. It is dominated by the mid-altitude mountains in the Northwest and has little alpine influence from the tributary Iller in the South. Therefore the present runoff regime is predominantly characterised by rain (pluvial). Donauwoerth is a medium sized runoff-river power plant with a mean annual hydroelectric power generation of approx. $60 \mathrm{GWh}$ and a maximum turbine discharge of $200 \mathrm{~m}^{3} / \mathrm{s}$.

(2) The Wasserburg runoff-river power plant at the lower part of the river Inn with a catchment area of $11,980 \mathrm{~km}^{2}$ is mostly influenced by the snow storage and also partly by the ice storage of the Central Alps. The present runoff regime is predominantly influenced by snow-melt (nival). Wasserburg is a large runoff-river power plant with a mean annual hydroelectric power generation of approx. $150 \mathrm{GWh}$ and a maximum turbine discharge of approx. $500 \mathrm{~m}^{3} / \mathrm{s}$.

(3) The Kaunertal reservoir hydropower plant has a small catchment area of $279 \mathrm{~km}^{2}$ and is situated in a highly glaciated alpine head-watershed in the Austrian Central Alps. Therefore the present runoff regime is predominantly composed by the snow and ice storage (glacio-nival). With a mean annual hydroelectric power generation of $661 \mathrm{GWh}$, the power plant has a maximum turbine discharge of $54 \mathrm{~m}^{3} / \mathrm{s}$ and a mean hydraulic head of $844 \mathrm{~m}$, depending on the filling line of the Gepatsch reservoir. The reservoir outflow and storage volume is determined using a standard monthly operation plan (see Figure 3).

\subsubsection{Contribution of the Runoff Components Rain, Snow- and Ice-Melt}

The regional hydrological differences of the three hydropower plants can be described, besides different regional precipitation patterns, by the contribution of the runoff components rain, snow- and ice-melt. Prasch [39] and Weber et al. [10] presented a new technique to model the runoff components rain, snow- and ice-melt for bigger watersheds with the hydrological model PROMET. By different model run settings, the snow- and ice-melt as well as the liquid fraction of precipitation can be calculated quantitatively for each grid cell. Ice-melt denotes the water released from the ice body of the snow-free glacier surface, which is modelled in detail by the energy-mass-balance model SURGES [11,39], snow-melt denotes the water that contributes to runoff from snow-melt in the watershed [9]. For the future simulations one of the four climate scenarios of the climate trend REMO regional was chosen exemplarily as a medium climate scenario.

Regarding the reference decade, the Wasserburg hydropower plant receives with $381 \mathrm{~m}^{3} / \mathrm{s}$ the highest mean annual runoff (Figure 11). Although the catchment area of Donauwoerth is larger than that of Wasserburg, this hydropower plant only receives $208 \mathrm{~m}^{3} / \mathrm{s}$. The mean annual fill rate of the Gepatsch reservoir is $11 \mathrm{~m}^{3} / \mathrm{s}$. At Donauwoerth, the mean annual runoff is supplied mostly by rain $(84 \%)$ with a smaller proportion of snow-melt (16\%). Compared with Donauwoerth, the snow-melt runoff contribution (35\%) of the more alpine influenced Wasserburg site is considerably higher. There, 
the runoff is triggered in addition by a small proportion of ice-melt (5\%) due to its glaciated area of $2 \%$. The Kaunertal site, with its $20 \%$ glaciated head-watershed, has a large fraction of snow- (39\%) and ice-melt (19\%). However, the rain contribution is highest at all sites.

Figure 11. Contribution of the runoff components rain (dark blue), snow- (light blue) and ice-melt (white) at the hydropower plants (a) Donauwoerth, (b) Wasserburg and (c) Kaunertal for the decades 1991-2000, 2021-2030 and 2051-2060. The future decades are simulated under the terms of a medium climate scenario of the climate trend REMO regional. Total mean annual runoff values $\left(\mathrm{mm}\right.$ and $\left.\mathrm{m}^{3} / \mathrm{s}\right)$ and the glaciated area $(\%)$ are listed below the pie charts.

a) Donauwoerth (Danube) catchment area: $12,693 \mathrm{~km}^{2}$

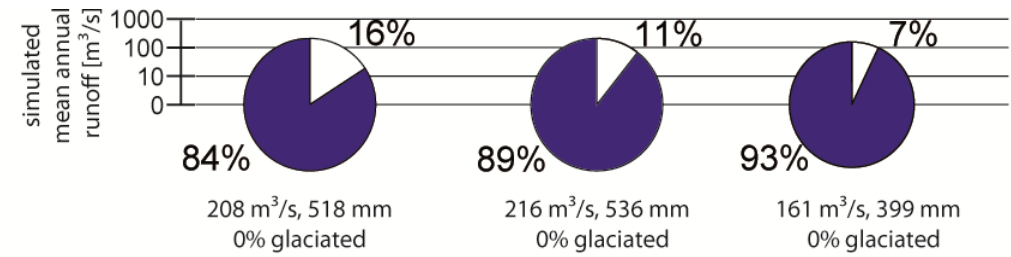

b) Wasserburg (Inn) catchment area: $11,980 \mathrm{~km}^{2}$

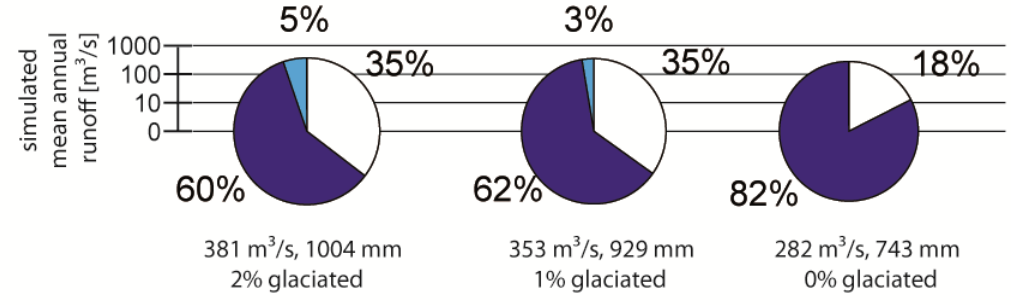

c) Kaunertal (Gepatsch reservoir) catchment area: $279 \mathrm{~km}^{2}$

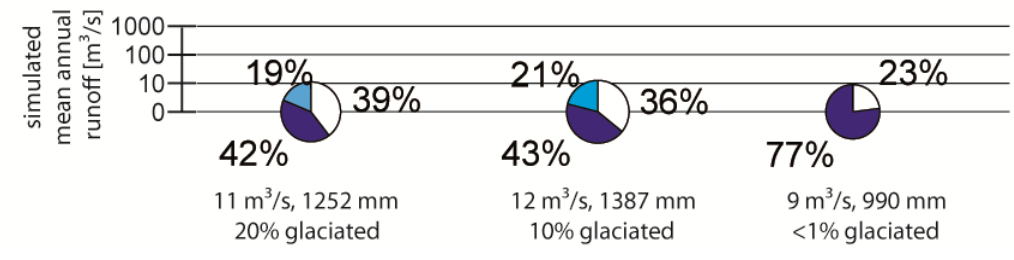

In the future, all three hydropower plants experience a decline of the mean annual runoff, in particular in the second future decade, because of a considerable decrease in water availability due to a decrease in the mean annual precipitation and an increase in evapotranspiration. Until 2060, the mean annual runoff accounts to $161 \mathrm{~m}^{3} / \mathrm{s}$ at Donauwoerth, to $282 \mathrm{~m}^{3} / \mathrm{s}$ at Wasserburg and to $9 \mathrm{~m}^{3} / \mathrm{s}$ at Kaunertal for the chosen climate scenario. Figure 11 shows the mean annual runoff components runoff, snow- and ice-melt for the reference and the two future decades. Whilst the contribution of rain increases in future, the contribution of snow-melt declines for all locations. Especially in the second scenario decade, the snow-melt decreases considerably to $7 \%$ at Donauwoerth, to $18 \%$ at Wasserburg and to $23 \%$ at Kaunertal. Even at the highly alpine location Kaunertal the decrease in snow-melt is strong, which results from the decrease of the snow storage even in high altitudes. At Wasserburg, the small proportion of mean annual ice-melt in the past becomes even smaller in 2021-2030 (3\%) because of an obviously higher contribution of the rain component. However, at Kaunertal the runoff component ice-melt increases slightly in 2021-2030 (21\%) due to an increased glacier melt. Because of a progressive glacier retreat, most of the glaciers will be extinct in the Eastern Alps until 2060 [10] with a total glacier coverage of less than $1 \%$ as shown in Figure 11. Therefore no ice-melt was simulated in 2051-2060. 
Overall, the results of the medium range climate scenario indicate for all three locations a clear quantitative future change of the mean annual runoff components, with an increase of the rain-component and a decrease of the components snow- and ice-melt. The other climate scenarios would show a similar development with more or less severe characteristics. Besides these quantitative changes of the mean annual runoff and its components, seasonal changes will occur [11]. The inter-annual courses of the compartment rain will shift due to changes in precipitation seasonality. The inter-annual courses of snow- and ice-melt, however, will shift towards an earlier outset of melting within the year. The reasons for the shift in snow-melt are a general reduction of snow fall compared to rain fall in winter and due to higher temperatures triggering earlier melting conditions in the year. The shift in ice melt is triggered mostly because glaciers are snow-free much earlier [11]. These effects cause different inter-annual runoff and consequently hydroelectric power generation patterns in the future, which will be shown for the three hydropower plants in the following.

\subsubsection{Development of Hydroelectric Power Generation}

Figure 12 illustrates the mean annual course of hydroelectric power generation of the Donauwoerth, Wasserburg and Kaunertal power plants for the decades 1991-2000, 2021-2030 and 2051-2060.

Figure 12. Development of mean monthly hydroelectric power generation at the hydropower plants (a) Donauwoerth, (b) Wasserburg and (c) Kaunertal for the reference decade 1991-2000 and the future decades 2021-2030 and 2051-2060 considering the climate trends IPCC regional, MM5 regional, REMO regional and Extrapolation.
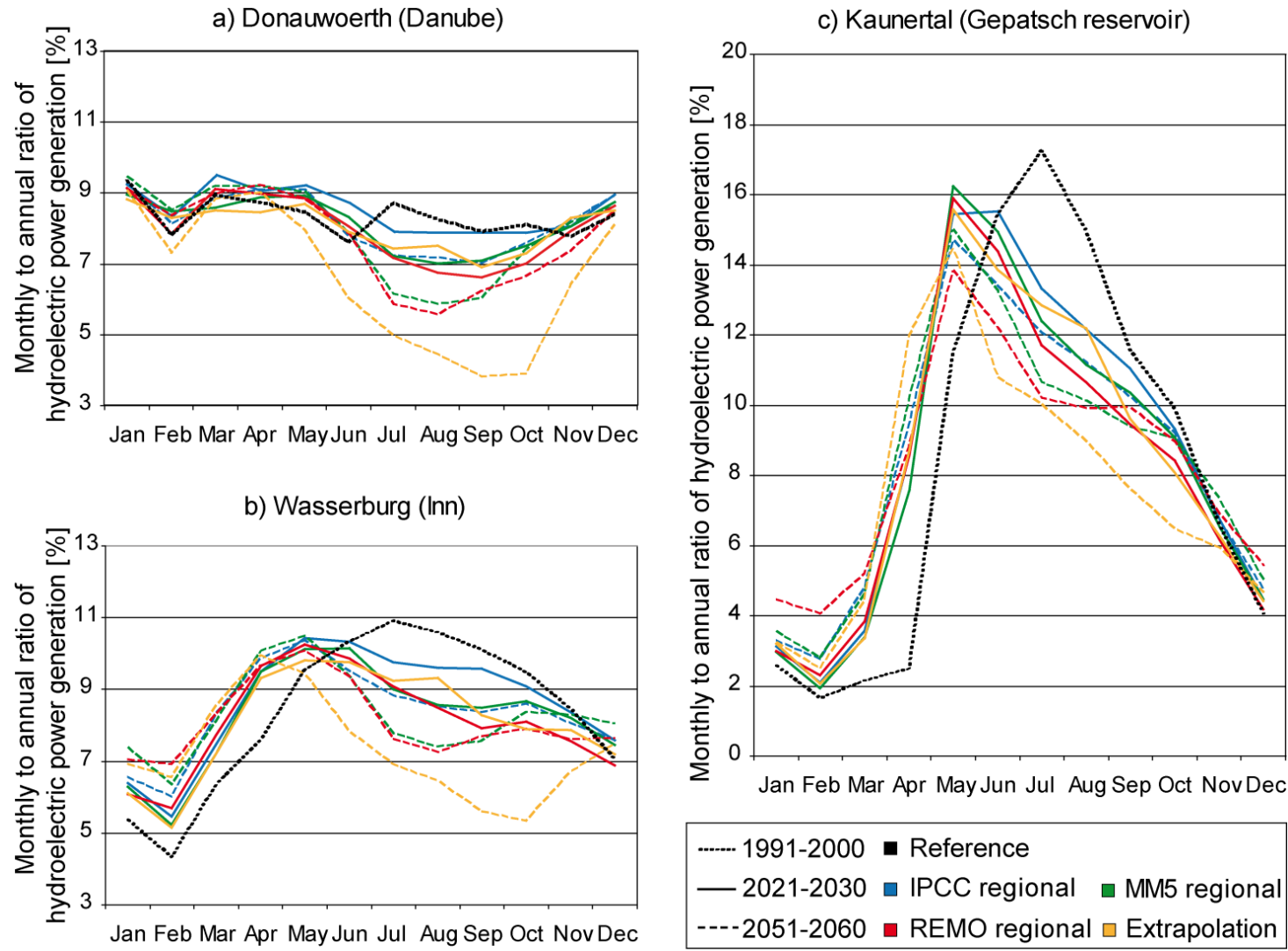
The curves are based on the ratio of monthly versus annual hydroelectric power generation for each decade for the four climate trends IPCC regional, MM5 regional, REMO regional and Extrapolation. The regional developments at the hydropower plants (a) Donauwoerth (Danube), (b) Wasserburg (Inn) and Kaunertal (Gepatsch reservoir) are discussed below:

(1) During the reference period the mean annual course of hydroelectric power generation at Donauwoerth is generally balanced with small peaks in January, March and July. In the past, the variability was very low; each month had a mean fraction of 8 to $9 \%$ of the mean total annual production. In the future, depending on the intensity of the respective climate trend, the production declines in the summer and autumn months and increases slightly in the winter months, leading to an increase of the monthly variability with a range from 4 to $9.5 \%$ of the mean total annual production considering all climate trends. Whilst the development for all trends is less pronounced until 2030 and for the trend IPCC regional also until 2060, due to a large decline in summer precipitation Extrapolation shows an extraordinarily severe decline in the second scenario period with distinct minima in September and October, whereas the trends MM5 regional and REMO regional indicate the future minimum in August. Because the runoff component rain has the highest influence at this location, the changes are predominately triggered by changes in precipitation with a distinct decrease in summer and a marked increase in winter. The future decrease of the runoff component snow-melt plays only a minor role because its contribution is generally very low. The development of hydroelectric power generation at this site is mainly influenced by changes in runoff variability. However, low-flow events become more severe in summer at less alpine influenced sites, leading to possible production restrictions, especially during the second simulation period.

(2) Regarding Wasserburg, the graph of hydroelectric power generation in the past shows a distinct annual cycle with a minimum in February due to the highest snow storage during this month, and its maximum in July depending on snow- and ice-melt and a the summer precipitation peak. The inter-annual variability is high with mean monthly fractions of 4.5 to $11 \%$ of the mean total annual production. The trends show a shift of the former July-maximum towards April and May, whilst the summer months with their former high production values tend to reach a clear minimum especially under the climate trend Extrapolation in the second scenario decade. This is triggered by a general reduction of the snow-melt and due to warmer temperatures to an earlier outset of the snow-melting season in spring. However, the former minimum in February still remains, because during this month the snow storage is still highest. But the reduction of the February-minimum indicates a higher winter rain contribution and a general decrease of the snow storage. Moreover, less low-flow occurs in winter, which leads to fewer restrictions in hydroelectric power generation. The main reason for this is the transformation of snowfall into rainfall in winter leading to more runoff in this time period. In contrast to Donauwoerth, the inter-annual variability experiences a slight decline with a future range of mean monthly fractions of 5.5 to $10.5 \%$ until 2060, because the future mean minima and maxima values are less pronounced than during the reference period. Summarized, at this location the inter-annual changes are mostly triggered by changes of the snow storage with an increasing influence of the 
runoff component rain. Thus, the development of the hydroelectric power generation will be more and more triggered by the runoff component rain.

(3) As described in Section 3.1, a standard monthly-based operation plan for the Gepatsch reservoir of the Kaunertal power plant is included, which shifts the natural annual runoff course due to assumed electricity demands. The management plan refers to present conditions and is not changed for the future simulations because of an uncertain development in energy strategies and demand. However, only monthly values were assumed, not taking into account detailed management structures. Due to no further detailed information about a higher temporal resolution, this assumption should be seen as a reasonable approach. The past annual course of the hydroelectric power generation has, because of its highly alpine character, a greater variability than Wasserburg or Donauwoerth with mean monthly fractions of 2 to $17 \%$ of the mean total annual production. Although the implemented management plan shifts the reservoir inflows temporarily, in August a clear maximum occurred due to large snow- and ice-melting rates, whereas in February a clear minimum due to high winter snow storage, was observed. In the future, the development of the four climate trends is similar to Wasserburg, however, with a drastic decline in ice-melt influence until 2060. The monthly production variability decreases slightly during the decades 2021-2030 and 2051-2060 because of less pronounced mean minima and maxima values. But there still remains a high variability of 2.5 to $15 \%$ until 2060 . Like at the Wasserburg location, the reduction of the February-minimum indicates a higher winter rain contribution for the future, especially for the trend MM5 regional. Because of earlier snow-melt, glacier ice will become snow-free sooner in the year, which increases glacier melting. In 2051-2060 the highest energy production occurs in May for all four climate trends. Hydroelectric power generation will still be high during summer, but will experience a strong decline due to a decrease of the snow storage and glacier retreat resulting in less snow-and ice-melt, especially in the second future decade. This summer development is especially pronounced for the trend Extrapolation.

To summarize, the three hydropower plants show different annual courses of hydroelectric power generation for the reference and the two future decades. Besides slightly different precipitation patterns, the differences originate in the dissimilar contributions of the runoff components rain, snow- and ice-melt. Changes at less alpine sites (e.g., Donauwoerth) are predominantly influenced by rain trends and lead to an increase in annual variability with a considerable minimum in summer to autumn. The development at alpine sites (Wasserburg and Kaunertal), reflect furthermore changes in the snow storage and for glaciated headwaters also in the ice storage leading to a slight decrease in annual variability and a shift of the maximum production from summer to spring.

\section{Conclusions}

In order to face and overcome future development tendencies, different adaptation measures could be considered for hydropower planning strategies. Thereby quantitative, seasonal and regional tendencies, as analysed in this study, should be taken into account, such as the altered seasonal rain patterns and the influence of the timing of the snow- and ice-melt on the hydroelectric power generation. To cover the growing energy demand, especially in the green energy sector, many regions already started to release feasibility studies to build new facilities and to enhance, reactivate and 
modernize old power plants [74,75]. However, all planning strategies should include possible trends considering climate change conditions. This is also the case when considering, e.g., future energy market strategies and possibilities for the future composition of the energy mix.

For the Upper Danube basin hydroelectric power generation will be considerably influenced by regional climate change. Future precipitation changes and temperature increase will trigger changes in the hydrological cycle. These effects lead in turn to changes of the energy production as shown in this study for 16 climate scenarios underlying four climate trends based on the global IPCC-SRES-A1B scenario. The general trend of hydroelectric power generation for all hydropower plants in the Upper Danube watershed until 2060, as analysed in Section 4.2, indicates a decline with its severity depending on the selected climate trends. Whilst the summer values experience a decrease with a large annual variability within each scenario, the winter values increase with a low variability until 2060. Moreover, changes in the runoff components rain, snow- and ice-melt trigger seasonal and regional changes in hydroelectric power generation as shown in Section 4.3. Less alpine sites, which are predominantly influenced by the runoff component rain, show an increase in future annual variability with a considerable minimum in summer to autumn due to less future precipitation during this season. At alpine sites, the presently quite large proportion of the runoff component snow-melt and in glaciated headwaters also the ice-melt decreases leading to a slight decrease in annual variability and a shift of the peak production from summer to spring. Due to a larger contribution of the runoff component rain and less influence of the component snow- and ice-melt for the whole Upper Danube, the seasonal patterns become more similar in all parts.

To give an outlook and to make some critical reflections, the following points should be considered. This modelling approach shows a plausible future development under climate change conditions with the advantage of taking into account seasonality, specific runoff components and the development of single hydropower plants and thus the possibility of considering regional differences. However, climate projections should be seen as scenarios and the model technique as a plausible representation of physical conditions. Firstly, climate change can be simulated by different scenarios indicating varying developments, which should be seen as a range of possible future developments. But, when considering the simulated results, uncertainties of the global emission scenarios and the regional climate assumptions should be taken into account. For this study, the medium ranged, quite probable global IPCC-SRES-A1B emission scenario [1] was chosen for the 16 climate scenarios based on four regional climate trends. The resulting simulations show a plausible range of future development of energy production in the Upper Danube basin. However, further assumptions on emission scenarios or regional climate trends as well as the consideration of different time periods can lead to a larger or smaller extent of future changes. Moreover, there are still more uncertainties in the application of hydrological modelling approaches in climate change scenario simulations as for instance, besides the uncertainty in the future greenhouse gas emissions, there are also uncertainties in the resulting changes in climate, changes in water management practices like irrigation and water supply, land use changes, impacts of economic change, population development and many more. Accordingly, these uncertainties in the results of scenario studies should always be considered. Secondly, with the fully distributed hydrological model PROMET and its coupled hydropower module used in this study, each runoff-river and reservoir power plant was considered individually taking into account the advantage to calculate the capacity of each hydropower plant with its individual parameterization, instead of 
transferring future runoff projections to the future hydropower situation, as shown in other studies. Regarding the simulated mean annual hydroelectric power generation they highly match the actual validated values. In addition the short term validation of daily generation at runoff-river power plants proves the capabilities of PROMET to reproduce the dynamic of runoff and power generation. However, for a daily or hourly time step more information of each individual power plant would be necessary. As hydroelectric power generation is influenced by extreme low-flow and flood events, e.g., due to restrictions, further research on this topic is certainly of interest. Although PROMET performs very well in generating reasonable runoff and hydroelectric power generation values, there are still some modelling uncertainties, e.g., displaying extreme flood events [32]. Moreover, due to a lack of available information, the implemented monthly-based reservoir operation plans, referred to present conditions, are only based on best guess assumptions. Further knowledge, e.g., provided by hydropower plant operators about the operation rules, the dependence of reservoir operation on short term electricity prices and a finer temporal resolution should be considered in the simulations and would consequently improve the results. In the future, the implemented reservoir management scenarios will certainly change due to changing energy markets, energy demand and reservoir functions. These changes however, are not considered in this study, but should be addressed in further research. Additionally, it would certainly be interesting to develop adaptation strategies as shown, e.g., in Payne et al. [26] to mitigate reservoir system performance losses due to climate change by examining several alternative reservoir operating policies.

\section{Acknowledgements}

The authors thank the German Federal Ministry of Education and Research $(b m b+f)$ and the Free State of Bavaria for funding the project GLOWA-Danube. The provision of meteorological and hydrological data by the German Weather Service (DWD), the Austrian Weather Service (ZAMG) and the Environmental Agency of the Free State of Bavaria (LfU) is gratefully acknowledged.

\section{References}

1. IPCC. Climate Change 2007: The Physical Science Basis; Contribution of Working Group I to the Forth Assessment Report of the Intergovernmental Panel on Climate Change; IPCC: Cambridge, UK, 2007.

2. REN21 (Renewable Energy Policy Network for the 21st Century). Renewables 2010. Global Status Report; REN21 Secretary: Paris, France, 2010.

3. Energiestatus Österreich. Bundesministerium für Wirtschaft, Familie und Jugend: Vienna, Austria. 2011. Available online: http://www.bmwfj.gv.at/EnergieUndBergbau/Energieversorgung/ Documents/A4_Kern_doppelseitig\%20gross\%20\%28korr\%29.pdf (accessed on 18 August 2011).

4. Wasserkraftnutzung. Fakten und Zahlen. Bundesamt für Energie: Bern, Switzerland, 2010. Available online: http://www.bfe.admin.ch/themen/00490/00491/index.html?lang=de\&dossier_ $\mathrm{id}=00803$ (accessed on 18 August 2011).

5. Schaefli, B.; Hingray, B.; Musy, A. Climate change and hydropower production in the Swiss Alps: Quantification of potential impacts and related modelling. Hydrol. Earth Syst. Sci. 2007, 11, 1191-1205. 
6. Beniston, M.; Stoffel, M.; Hill, M. Impacts of climate change on water and natural hazards in the Alps: Can current water governance cope with future challenges? Examples from the European "ACQWA" project. Environ. Sci. Policy 2011, in press.

7. Blöschl, G.; Schöner, W.; Kroiß, H.; Blaschke, A.P.; Böhm, R.; Haslinger, K.; Kreuzinger, N.; Merz, R.; Parajka, J.; Salinas, J.L.; et al. Anpassungsstrategien an den Klimawandel für Österreichs Wasserwirtschaf-Ziele und Schlussfolgerungen der Studie für Bund und Länder. Oesterr. Wasser-Abfallwirtsch. 2011, 1-2, 1-20.

8. Klein, B.; Krahe, P., Lingemann, I.; Nilson, E.; Kling, H.; Fuchs, M. Assessing Climate Change Impacts on Water Balance in the Upper Danube Basin based on a 23 Member RCM Ensemble. In Proceedings of the XXVth Conference of the Danubian Countries, Budapest, Hungary, 16-17 June 2011.

9. Dobler, C.; Stötter, J.; Schöberl, F. Assessment of climate change impacts on the hydrology of the Lech Valley in northern Alps. J. Water Clim. Change 2010, 1, 207-218.

10. Weber, M.; Braun, L.; Mauser, W.; Prasch, M. Contribution of rain, snow- and icemelt in the Upper Danube discharge today and in the future. Geogr. Fis. Dinam. Quat. 2010, 33, 221-230.

11. Weber, W.; Braun, L.; Mauser, W.; Prasch, M. Die Bedeutung der Gletscherschmelze für den Abfluss der Donau gegenwärtig und in der Zukunft. Mitt. Hydrogr. Dienstes Österreich 2009, 86, $1-29$.

12. Weingartner, R., Viviroli, D.; Schädler, B. Water resources in mountain regions: A methodological approach to assess the water balance in a highlandlowland-system. Hydrol. Process. 2007, 21, 578-585.

13. Horton, P.; Schaefli, B.; Mezghani, A.; Hingray, B.; Musy, A. Assessment of climate-change impacts on alpine discharge regimes with climate model uncertainty. Hydrol. Process. 2006, 20, 2091-2109.

14. Beniston, M. Mountain climates and climatic change: An overview of processes focusing on the European Alps. Pure Appl. Geophys. 2005, 162, 1587-1606.

15. Zierl, B.; Bugmann, H. Global change impacts on hydrological processes in Alpine catchments. Water Resour. Res. 2005, 41, 1-13.

16. Beniston, M. Climatic change in mountain regions: A review of possible impacts. Clim. Change 2003, 59, 5-31.

17. Viviroli, D.; Weingartner, R.; Messerli, B. Assessing the hydrological significance of the world's mountains. Mt. Res. Dev. 2003, 23, 32-40.

18. Arnell, N.W. The effect of climate change on hydrological regimes in Europe: A continental perspective. Glob. Environ. Change 1999, 9, 5-23.

19. Huss, M.; Jouvet, G.; Farinotti, D.; Bauer, A. Future high-mountain hydrology: A new parameterization of glacier retreat. Hydrol. Earth Syst. Sci. 2010, 14, 815-829.

20. Braun, L.; Weber, M.; Schulz, M. Consequences of climate change for runoff from Alpine regions. Ann. Glaciol. 2000, 31, 19-25.

21. Stanzel, P.; Nachtnebel, H.P. Mögliche Auswirkungen des Klimawandels auf den Wasserhaushalt und die Wasserkraftnutzung in Österreich. Oesterr. Wasser-Abfallwirtsch. 2010, 62/9-10, 180-187. 
22. Kuhn, M.; Olefs, M. Auswirkungen von Klimaänderungen auf das Abflussverhalten von vergletscherten Einzugsgebieten im Hinblick auf die Speicherkraftwerke. In StartClim2007E; Institute of Meteorology and Geophysics, University of Innsbruck: Vienna, Austria, 2007.

23. Lehner, B.; Czisch, G.; Vassolo, S. The impact of global change on hydropower potential of Europe: A model-based analysis. Energy Policy 2005, 33, 839-855.

24. Piot, M. Auswirkungen der klimaerwärmung auf die wasserkraftproduktion der schweiz. Wasser Energie Luft 2005, 97, 365-367.

25. Madani, K.; Lund, J.R. Estimated impacts of climate warming on California's high-elevation hydropower. Clim. Change 2010, 102, 521-538.

26. Payne, J.T.; Wood, A.W.; Hamlet, A.F.; Palmer, R.N.; Lettenmaier, D.P. Mitigating the effects of climate change on water resources of the Columbia river basin. Clim. Change 2004, 62, 233-256.

27. Vicuna, S.; Dracup, J.A. The evolution of climate change impact studies on hydrology and water resources in California. Clim. Change 2007, 82, 327-350.

28. Christensen, N.; Wood, A.W.; Voisan, N.; Lettenmaier, D.P.; Palmer, N.R. The effect of climate change on the hydrology and water resources of the Colorado River basin. Clim. Change 2004, 62, 337-363.

29. GLOWA-Danube Projekt. Global Change Atlas Einzugsgebiet Obere Donau, 6th ed.; LMU Munich, Department of Geography: Munich, Germany, 2010. Available online: http://www.glowa-danube.de (accessed on 27 September 2011).

30. Mauser, W.; Ludwig, R. GLOWA-Danube-A Research Concept to Develop Integrative Techniques, Scenarios and Strategies Regarding Global Changes of the Water Cycle. In Climate Change: Implications for the Hydrological Cycle and for Water Management, Advances in Global Research; Beniston, M., Ed.; Kluwer Academic Publishers: Dordrecht, The Netherlands and Boston, MA, USA, 2002; Volume 10, pp. 171-188.

31. Ludwig, R.; Mauser, W.; Niemeyer, S.; Colgan, A.; Stolz, R.; Escher-Vetter, H.; Kuhn, M.; Reichstein, M.; Tenhunen, J.; Kraus, A.; et al. Web-based modelling of energy, water and matter fluxes to support decision making in mesoscale catchments-The integrative perspective of GLOWA Danube. Phys. Chem. Earth 2003, 28, 621-634.

32. Mauser, W.; Bach, H. PROMET-Large scale distributed hydrological modelling to study the impact of climate change of the water flows of mountain watersheds. J. Hydrol. 2009, 376, 362-377.

33. Prasch, M.; Bernhardt, M.; Weber, M.; Strasser, U.; Mauser, W. Physically based Modelling of Snow Cover Dynamics in Alpine Regions. In Proceedings of the Innsbruck Conference, Innsbruck, Austria, 15-17 October 2007; Volume 2, pp. 323-330.

34. Amt der Tiroler Landesregierung, Abteilung Wasser-, Forst- und Energierecht. Tiroler Energiestrategie 2020. Grundlage für die Tiroler Energiepolitik; Tiroler Landesregierung, Abteilung Wasser-, Forst- und Energierecht: Innsbruck, Austria, 2008.

35. Bayerisches Staatsministerium für Wirtschaft, Infrastruktur, Verkehr und Technologie. Eckpunkte der bayerischen Energiepolitik; Bayerisches Staatsministerium für Wirtschaft, Infrastruktur, Verkehr und Technologie: Munich, Germany, 2008.

36. Strasser, U.; Mauser, W. Modelling the spatial and temporal variations of the water balance for the Weser catchment 1965-1994. J. Hydrol. 2001, 254, 199-214. 
37. Prasch, M.; Mauser, W. GLOWA-Danube: Integrative Techniques, Scenarios and Strategies Fort he Future of Water in the Upper Danube Basin. In Proceedings of the XXVth Conference of the Danubian Countries in Budapest, Budapest, Hungary, 16-17 June 2011.

38. Prasch, M.; Marke, T.; Strasser, U.; Mauser, W. Large scale integrated hydrological modelling of the impact of climate change on the water balance with DANUBIA, Adv. Sci. Res. 2011, 7, 61-70.

39. Prasch, M. Distributed Process Oriented Modelling of the Future Impact of Glacier Melt Water on Runoff in the Lhasa River Basin in Tibet. Ph.D. Thesis, Faculty of Geosciences, LMU Munich, Munich, Germany, 2010. Available online: http://edoc.ub.uni-muenchen.de/13031/ (accessed on 25 August 2011).

40. Strasser, U.; Franz, H.; Mauser, W. Distributed Modelling of Snow Processes in the Berchtesgaden National Park (Germany). In Proceedings of the Alpine Snow Workshop, Munich, Germany, 5-6 October 2006; Volume 53, pp. 117-130.

41. Bayerisches Landesamt für Umwelt. Québec-Bavarian International Collaboration on Climate Change-Klimawandel und Flussgebietsmanagement, Hof, Germany, 2011. Available online: http://www.lfu.bayern.de/wasser/klima_wandel/projekte/kliflum/index.htm (accessed on 25 August 2011).

42. Climb Project. Climate Induced Changes on the Hydrology of Mediterranean Basins. Reducing Uncertainty and Quantifying Risk through an Integrated Monitoring and Modelling System, 2010. Available online: http://www.climb-fp7.eu (accessed on 25 August 2011).

43. Blöschl, G.; Montanari, A. Climate change impacts-Throwing the dice? Hydrol. Process. 2010, 24, 374-381.

44. Beven, K. Changing ideas in hydrology-The case of physically-based models original research article. J. Hydrol. 1989, 105, 157-172.

45. Cunge, J.A. On the subject of a flood propagation computation method (Muskingum method). J. Hydraul. Res. 1969, 7, 205-230.

46. Todini, E. A mass conservative and water storage consistent variable parameter Muskingum-Cunge approach. Hydrol. Earth Syst. Sci. 2007, 4, 1549-1592.

47. Ostrowski, M.; Lohr, H. Modellgestützte bewirtschaftung von talsperrensystemen Wasser und Abfall 2002, 1-3, 40-45.

48. Nash, J.E.; Sutcliffe, J.V. River flow forecasting through conceptual models, a discussion of principles. J. Hydrol. 1970, 10, 282-290.

49. Schaefli, B.; Gupta, H.V. Do Nash values have value? Hydrol. Process. 2007, 21, 2075-2080.

50. Wenn bei Starkregen die Produktion einbricht. Energiespektrum 2010, 9-10, 40-41. Available online: http://www.energiespektrum.de/index.cfm?pid=1705\&pk=98082 (accessed on 27 September 2011).

51. EEX transparency platform publishing market-relevant energy generation and consumption data. European Energy Exchange AG: Leipzig, Germany 2011. Available online: http://www. transparency.eex.com/en/ (accessed on 28 June 2011).

52. Mauser, W.; Prasch, M.; Strasser, U. Physically based Modelling of Climate Change Impact of Snow Cover Dynamics in Alpine Regions Using a Stochastic Weather Generator. In Proceedings of the International Congress on Modelling and Simulation MODSIM07, Christchurch, New Zealand, 10-13 December 2007; pp. 2138-2145. 
53. Orlowsky, B.; Gerstengarbe, F.W.; Werner, P.C. A resampling scheme for regional climate simulations and its performance compared to a dynamic RCM. Theor. Appl. Climatol. 2007, 92, 209-223.

54. Yates, D.; Gangopadhyay, S.; Rajagopalan, B.; Strzepek, K. A technique for generating regional climate scenarios using a nearest neighbour algorithm. Water Resour. Res. 2003, 39, 1-15.

55. Buishand, T.A.; Brandsma, T. Multiscale simulation of daily precipitation and temperature in the Rhine Basin by nearest-neighbour resampling. Water Resour. Res. 2001, 37, 2761-2776.

56. Young, K.C. A multivariate chain model for simulating climatic parameters from daily data. J. Appl. Meteorol. 1994, 33, 661-671.

57. Richardson, C.W. Stochastic simulation of daily precipitation, temperature and solar radiation. Water Resour. Res. 1981, 17, 182-190.

58. Semenov, M.A.; Brooks, R.J.; Barrow, E.M.; Richardson, C.W. Comparison of WGEN and LARS-WG stochastic weather generators for diverse climates. Clim. Res. 1998, 10, 95-107.

59. Racsko, P.; Szeidl, L.; Semenov, M.A. A serial approach to local stochastic weather models. Ecol. Model. 1991, 57, 27-41.

60. Jacob, D.; Goettel, H.; Kotlarski, S.; Lorenz, P.; Sieck, K. Klimaauswirkungen und Anpassungen in Deutschland. In Climate Change; Federal Environmental Agency: Dessau-Roßlau, Germany, 2008; Volume 11/08.

61. Frei, C.; Christensen, J.H.; Déqué, M.; Jacob, D.; Jones, R.G.; Vidale, P.L. Daily precipitationstatistics in regional climate models: Evaluation and intercomparison for the European Alps. J. Geophys. Res. 2003, 108, doi:10.1029/2002JD002287.

62. Beniston, M.; Stephenson, D.B.; Christensen, O.B.; Ferro, C.A.T.; Frei, C.; Goyette, S.; Halsnaes, K.; Holt, T.; Jylhä, K.; Koffi, B.; et al. Future extreme events in European climate: An exploration of regional climate model projections. Clim. Change 2007, 81, 71-95.

63. ENSEMBLES: Climate Change and Its Impacts Summary of Research and Results from the ENSEMBLES Project; van der Linden, P., Mitchell, J.F.B., Eds.; Met Office Hadley Centre: Exter, UK, 2009; p. 164. Available online: http://www.ensembles-eu.org (accessed on 25 August 2011).

64. Jacob, D.; Bärring, L.; Christensen, O.B.; Christensen, J.H.; de Castro, M.; Déqué, M.; Giorgi, F.; Hagemann, S.; Hirschi, M.; Jones, R.; et al. An inter-comparison of regional climate models for Europe: model performance in present-day climate. Clim. Change 2007, 81, 31-52.

65. Pfeiffer, A.; Zaengl, G. Validation of climate-mode MM5-simulations for the European Alpie region. Theor. Appl. Climatol. 2009, 101, 93-108.

66. Reiter, A.; Weidinger, R.; Mauser, W. Recent climate change at the Upper Danube-A temporal and spatial analysis of temperature and precipitation time series. Clim. Change 2011, doi:10.1007/s10584-011-0173-y.

67. Mann, H.B. Nonparametric test against trends. Econometrica 1945, 13, 245-259.

68. Kendall, M.G. Rank Correlation Methods, 4th ed.; Griffin: London, UK, 1970.

69. Mauser, W.; Marke, T. Climate Change and Water Resources: Scenarios of Low-flow Conditions in the Upper Danube River Basin. IOP Conf. Ser. 2008, 4, doi:10.1088/1755-1307/4/1/012027. 
70. Die Wettbewerbsfähigkeit von großen Laufwasserkraftwerken im liberalisierten deutschen Strommarkt. Endbericht für das Bundesministerium für Wirtschaft und Arbeit (BMWA); Fichtner GmbH \& Co KG: Stuttgart, Germany, 2003. Available online: http://www.emissionshandelfichtner.de/pdf/BMWA_Langfassung.pdf (accessed on 12 May 2011).

71. Mittlere Donaukraftwerke $A G(M D K)$; BEW (Bayerische Elektrizitätswerke GmbH): Augsburg, Germany, 2011. Available online: http://www.bew-augsburg.de/cms_bew_inter/kraftwerke/ wasserkraft/technikmdk.asp (accessed on 12 May 2011).

72. Strasser, K.-H. Aktuelle Neubauprojekte der E.ON Wasserkraft-Verändertes Umfeld und deren Auswirkungen. Wasserwirtschaft 2007, 10, 102-104.

73. Das Kraftwerk Kaunertal; TIWAG (Tiroler Wasserkraft AG): Innsbruck, Austria, 2006.

74. Wasserkraftausbau; TIWAG (Tiroler Wasserkraft AG): Innsbruck, Austria, 2011. Available online: http://www.tiroler-wasserkraft.at/de/hn/wasserkraftausbau/index.php (accessed on 9 June 2011).

75. E.ON Wasserkraft $\mathrm{GmbH}$ and Bayerische Elektrizitätswerke GmbH. Masterplan. Ausbaupotentiale Wasserkraft in Bayern. Bericht aus Sicht der beiden großen Betreiber von Wasserkraftanlagen in Bayern; Landshut: Augsburg, Germany, 2009. Available online: http://www.lfu.bayern.de/wasser/fachinformationen/fliessgewaesser_wasserkraft/anlagenstatistik/ doc/potentialstudie.pdf (accessed on 9 June 2011).

(C) 2011 by the authors; licensee MDPI, Basel, Switzerland. This article is an open access article distributed under the terms and conditions of the Creative Commons Attribution license (http://creativecommons.org/licenses/by/3.0/). 